\title{
Workplace environmental conditions and life satisfaction in Spain
}

\author{
Inmaculada García-Mainara, Víctor M. Montuenga ${ }^{\mathrm{a},},{ }^{*}$, María Navarro-Paniagua $^{\mathrm{b}}$ \\ ${ }^{a}$ University of Zaragoza, Economic Analysis, Gran Vía 2, 50005 Zaragoza, Spain \\ ${ }^{\mathrm{b}}$ Lancaster University Management School, Lancaster University, LA1 4YX, UK
}

\begin{abstract}
This paper expands the research on subjective well-being and outdoor environmental conditions by considering environmental conditions indoors. Specifically, we examine the impact on life satisfaction of self-perceived levels of air and noise pollution in the workplace. We provide a monetary valuation of these environmental conditions, using the life-satisfaction approach. Our results demonstrate that poor air quality and high noise levels in the workplace markedly diminish life satisfaction. This holds even after we control for potential endogeneity arising from simultaneity of self-perceived workplace environmental variables and life satisfaction, by employing an instrumental variable strategy.
\end{abstract}

Keywords: environmental pollution; acoustic comfort; air quality; subjective wellbeing; life satisfaction.

\footnotetext{
* Corresponding author. Victor Manuel Montuenga Gomez, Tel.: +(34) 976 761778; fax: +(34) 976 761996. e-mail: vimontue@unizar.es

Inmaculada Garcia-Mainar, e-mail: igarcia@unizar.es

Maria Navarro-Paniagua, e-mail: m.navarropaniagua@lancaster.ac.uk

This study analysed existing data that are available from the Spanish Ministry of Employment and Social Security. Further documentation about the data that were used in this paper is available from the Lancaster University data archive at http://dx.doi.org/10.17635/lancaster/researchdata/42
} 


\section{Introduction}

It is well established that several factors, in addition to income, influence subjective wellbeing (SWB hereafter), including unemployment and inflation (Clark and Oswald, 1994; Di Tella et al., 2001; Oswald, 1997), health (Blanchflower and Oswald, 2008), and education (Cuñado and Pérez-Gracia, 2012), along with individual variables such as age, gender, and marital and occupational status (see Dolan et al., 2008, for a survey). In this context, some research has focused on the potential effects of environmental conditions on well-being, analysing the relationship between SWB and air pollution (see Welsch 2009 and Welsch and Kühling, 2009, for recent surveys). The consideration of variables affecting quality of life, such as pollution, complements the link between income and SWB (Ferrer-i-Carbonell and Gowdy, 2007).

While many studies have focused on the effect of outdoor environmental conditions, there is relatively little research on how well-being is related to environmental conditions indoors, i.e. at home or at the workplace. This line of research appears to have been restricted, so far, to studies of the relationship between individual characteristics, and health and safety, without considering the broader determinants of well-being. Particularly in developed countries, individuals spend a large part of their time indoors, so that conditions at home and at the workplace are of significance in determining general well-being and life satisfaction. In their survey of buildings and the environment, Frontczak and Wargocki (2011) conclude that, when indoor environmental conditions can be controlled by employees, satisfaction improves. In that paper, conditions of thermal, visual, and acoustic comfort, as well as of air ventilation, are shown to be important factors in shaping satisfaction at the workplace, and life satisfaction in general. One study that considers whether pollution, grime, or other environmental problems at home influence life satisfaction - without taking outdoor environmental conditions into account - is that of Ferrer-i-Carbonell and Gowdy (2007). We believe that considering both outdoor and indoor conditions is a promising approach. For instance, airport noise may seriously erode the well-being of individuals living close to airports, even if they are working in an otherwise comfortable and pleasant environment. By contrast, a bar-tender may live in a quiet and clean neighbourhood, but spend more than a third of the time in a noisy workplace, with this having consequences on SWB.

The major contribution of our paper is that we combine two strands of research: the one that considers the association between environmental quality, climate, and SWB 
measures, and the literature relating employee perceptions of the work environment to well-being and life satisfaction. To our knowledge, this approach has not been addressed empirically so far. To that end, this paper expands the research on SWB and outdoor environmental conditions by considering environmental conditions indoors. Specifically, we examine the impact of self-perceived levels of air and noise pollution in the workplace. Since these variables are, by definition, subjective, we address the fact that they may be influenced by individual SWB, and that unobserved individual characteristics may also have discernible effects. Simultaneity and omitted variables generate a problem of potential endogeneity that can lead to biases in our estimates of these effects on SWB, which we deal with by employing an instrumental variable strategy, which constitutes our second major contribution. Specifically, we use a regional noise prevention reform, enacted in 2009 , as a source of exogenous variation in perceived noise levels, to take into account potential endogeneity.

A final contribution of our paper is that, by following the life satisfaction approach, we are able to provide a monetary value of environmental quality, both at the overall and the workplace level. Reported SWB can be considered as the empirical approximation of individual welfare, thus the regressions of SWB measures of income, environmental conditions, and other characteristics are the basis for our evaluation of public good in welfare terms. On its own, the estimated coefficients for the environmental good offer a direct value in terms of SWB, but they can also be used to calculate the implicit willingness-to-pay; that is, the increase in income that an individual would need to receive to compensate for a given loss in environmental quality (see Frey et al., 2010, for a comprehensive review of the life-satisfaction approach).

The joint consideration of indoor and outdoor conditions may provide substantial and robust implications for policy-oriented measures, at the aggregate national level, in the belief that environmental conditions influence present and future SWB (Ferreira et al., 2013; Welsch, 2009); and at the firm or workplace level, since an evaluation of working conditions can be of help in the adequate design of HR-management strategies, and in stimulating productivity. In this context, it is important to examine the determinants of SWB, especially those that come under regulation, since there exist a number of EU Directives limiting the concentration of pollutants, while others establish the minimum requirements for occupational health and safety in the workplace (noise, visibility, etc....). ${ }^{1}$

\footnotetext{
${ }^{1}$ http://ec.europa.eu/environment/air/quality/legislation/existing_leg.htm and http://ec.europa.eu/environment/noise/home.htm for the former, and https://osha.europa.eu/en/legislation/index_html for the latter.
} 
In the case of Spain, we have a rich dataset of subjective information. We use the Quality of Working Life Survey (Encuesta de Calidad de Vida en el Trabajo, ECVT hereafter), which is an appropriate dataset for studying life satisfaction in Spain. We match various measures obtained from national statistics to account for air pollution, climate, and other regional variables, including objective measures of air quality, and subjective assessments of the workplace environment. Our results show that the perception of noise nuisance and poor ventilation in the workplace markedly diminish life satisfaction. This holds even after simultaneity and unobserved heterogeneity are taken into account. The IV point-estimates are shown to be quite different from noninstrumented estimates, revealing the existence of endogeneity problems and the importance of controlling for them.

The remainder of the paper is structured as follows. Section 2 briefly surveys the existing literature on well-being and environmental conditions. Section 3 describes the data set. Section 4 discusses our empirical model of life satisfaction, outdoor air quality and indoor self-perception of workplace environmental conditions. Section 5 presents our conclusions.

\section{Literature review}

Easterlin's (1974) claim that well-being does not depend exclusively on income has led researchers to consider a wide range of factors that may affect SWB, such as a concern for outdoor environmental conditions, a topic which has gained popularity in recent years. ${ }^{2}$ One of the first studies on the topic, Frijters and van Praag (1998), analyses the impact of changes in climate variables on individual well-being in Russia, but the bulk of the research has been concerned with air quality and pollution. ${ }^{3}$ The typical finding is that indicators of air pollution $\left(\mathrm{PM}_{10}, \mathrm{SO}_{2}\right.$, and $\left.\mathrm{CO}_{2}\right)$ are negatively correlated with measures of SWB. At the cross-country level, studies such as Welsch (2002, 2003, 2006 and 2007) and Menz and Welsch (2010) use aggregate data from the World Database of Happiness, finding a negative relationship between national average happiness and certain pollution indicators. Welsch $(2002,2007)$ uses cross-sectional data for 54 countries, while the other studies focus on a smaller panel of OECD countries. With the same database, Rehdanz

\footnotetext{
${ }^{2}$ Recent surveys of the relationship between economic factors and SWB are Bruni and Porta (2007), Di Tella and McCulloch (2006), Frey and Stutzer (2002) and MacKerron (2012). Other studies explicitly consider environmental conditions affecting SWB (Di Tella and MuCulloch, 2008; Ferrer-i-Carbonell, 2013). Surveys exclusively devoted to reviewing the literature on the relationship between environmental conditions and SWB are Welsch (2009), Welsch and Kühling (2009) and Welsch and Ferreira (2014).

${ }^{3}$ There are also several studies relating SWB to other factors, such as climate or weather (Brereton et al., 2008; Murray et al., 2013; Rehdanz and Maddison, 2005), noise (van Praag and Baarsma, 2005) and natural hazards (Carroll et al., 2009; Luechinger and Raschky, 2009).
} 
and Maddison (2005) explain differences in self-reported levels of happiness using climate variables (temperature and precipitation), finding that higher mean temperatures in the colder months increase happiness, while higher mean temperatures in the hotter months decrease happiness, with precipitation not being a significant factor. Also from an international perspective, but using individual level data, Di Tella and MacCulloch (2008), Luechinger (2010) and Ferreira et al. (2013) find that air pollution decreases life satisfaction.

Other papers use more spatially-disaggregated pollution data, along with individualbased measures of SWB concentrating on just one country or area: Cuñado and PérezGracia (2013) for Spain, Brereton et al. (2008) and Ferreira et al. (2006) for Ireland, Ferrer-i-Carbonell and Gowdy (2007) for the UK, Levinson (2012) for the US, Luechinger (2009) and Rehdanz and Maddison (2008) for Germany, and MacKerron and Mourato (2009) for the London area. The finding is similar to that of the studies that use aggregated data; degradation in air quality is associated with lower SWB. Van Praag and Baarsma (2005) and Rehdanz and Maddison (2008) are the only studies that address noise pollution in their analyses. The latter use individual-level data from the German socio-economic panel (GSOEP) to study the link between perceived levels of noise and air pollution in a given residential area, and self-reported happiness. Estimating their model via ordered probit techniques, their findings suggest that high noise levels and poor air quality diminish SWB. Additionally, by applying the hedonic model that values environmental conditions, they find that differences in the perceived levels of these environmental conditions are not capitalised into housing prices. MacKerron and Mourato (2009) analyse the connections between the self-reported happiness of a nonrepresentative sample of Londoners and environmental conditions, using both perceived and measured data on London's air quality, at a very high spatial resolution. Their ordinary least squares (OLS) results suggest that happiness is negatively correlated with both subjective and objective measures of air pollution. Ferrer-i-Carbonell and Gowdy (2007) study the effect of environmental awareness on individual well-being, with data from the British Household Panel Survey. Their ordered probit estimates show that environmental concerns affect happiness, even after controlling for personality traits.

Several studies use the life satisfaction approach to provide monetary valuation of the environmental public good. This approach allows for the computation of relative value between two different characteristics, expressed in unit terms. Ferreira and Moro (2010), Welsch $(2007,2009)$ and Welsch and Kühling (2009) describe and compare the standard methods of environmental valuation, including the life-satisfaction approach, which has 
been used in empirical studies (Cuñado and Pérez-Gracia, 2013; Levinson, 2012; Luechinger, 2009; Menz and Welsch, 2010; Welsch, 2002, 2007). ${ }^{4}$ Levinson (2012) finds that happiness in the US is related to air quality and weather indicators at the time and place of the survey. Using the life satisfaction approach, the author computes respondents' implicit willingness to pay for improved air quality. Luechinger (2009) combines individual information in panel data form, from the GSOEP, with matched pollution data, using an instrumental variable approach based on a natural experiment. $\mathrm{He}$ applies the life satisfaction approach supplemented by hedonic house- price regression techniques to calculate total willingness-to-pay.

In the case of Spain, there is only one prior study, by Cuñado and Pérez-Gracia (2013). Their results show a negative correlation between pollution indicators and happiness. Additionally, after controlling for a number of socio-economic variables affecting happiness, there remain significant regional differences in SWB, with climate and air pollution variables playing a significant explanatory role. By following the life satisfaction approach, these authors also calculate the monetary value of air quality and climate.

Our work is different in several respects. First, we consider not only global environmental conditions but also environmental conditions in the workplace. Second, we use a different dataset, the ECVT, which is representative at the national and the regional levels, providing a rich database of objective and self-reported information regarding the workplace. There is one more important, distinction: we take into account unobserved characteristics by means of an instrumental variable approach.

Regarding indoor environmental conditions, McCaughey et al. (2014) find that employee perceptions of workplace environmental conditions are related to individuallevel outcomes, such as well-being and job performance. Meta-analytic studies confirm that generalized beliefs about an organization's environmental influence guide subsequent behaviour and specific attitudes such as satisfaction (Carr et al., 2003; Parker et al., 2003). In their survey of the literature on buildings and environment, Frontczak and Wargocki (2011) conclude that outdoor climate and season influence comfort at the workplace, and thus are relevant factors affecting satisfaction, whereas personal characteristics are of less importance. Gupta and Kristensen (2008) find that having a satisfactory job environment is at least as important for health - which is an important determinant of SWB and workplace satisfaction - as income or socio-economic status.

\footnotetext{
${ }^{4}$ The life satisfaction approach has also been used for monetary valuation of airport noise (van Praag and Baarsma, 2005) and climate change (Murray et al., 2013; Rehdanz and Maddison, 2005).
} 


\section{Data}

Our empirical analysis employs four distinct data sources. The ECVT is an annual household-based survey of individuals selected to be nationally representative from the employed population over age 16, for the period from 2006 to 2010. It consists of a sample of repeated cross-sections, whose objective is to provide a tool for gathering substantive information concerning employee social relations, situations, attitudes, and values in the workplace, and examines variables of personal and job characteristics, including certain workplace environmental conditions. ${ }^{5}$ We match this data to temperature and precipitation data from the State Meteorological Agency (AEMET), pollution data from the Spanish Ministry of Agriculture, Food and the Environment (MAFE), and GDP-per-capita and unemployment rates from National Accounting (NA). All variables from these three latter sources are disaggregated at a 17-region (NUTS II) and year level.

\section{INSERT TABLE 1}

We select a subsample from the ECVT corresponding to employees, with 32,317 observations. Table 1 presents the variable definitions and certain descriptive statistics. While most of the definitions are self-contained, some referring to subjective information are worth explaining in brief. Regarding our dependent variable, in many studies, individuals are asked to report how happy they feel. In the survey we employ, as in other data sets, individuals are asked about their satisfaction with life. Whereas happiness refers to the individual's current situation, and is supposed to capture "affect"; life satisfaction is an individual's perception of how his/her life has been so far, showing a more evaluative character (Frey et al., 2010). Both terms are often used interchangeably in the economics literature, encompassed in the more general term of SWB, and this is the notion we have used so far in the general description of the topic and in the review of the literature. ${ }^{6}$ From here on, we use the term life satisfaction, since this notion is better suited to the question available in the dataset we employ: Please, rate between 0 (not satisfied at all), and 10 (very satisfied), your degree of satisfaction with your personal life.

\footnotetext{
5 The use of subjective information on the environment has been previously applied in research on the topic, e.g. Ferrer-i-Carbonell and Gowdy (2007); MacKerron and Mourato (2009); Rehdanz and Maddison (2008); Van Praag and Baarsma (2005).

${ }^{6}$ This is commonly considered as the empirical proxy of what Kahneman et al. (1997) call "experienced utility", as opposed to decision utility. For more detailed explanations on these concepts, see Diener et al. (1999), Frey et al. (2010), Kahneman et al. (1999), Kahneman and Krueger (2006) and MacKerron (2012).
} 
An additional matter referring to our dependent variable is whether life satisfaction is assumed to be ordinal-interpersonal comparable, or cardinal-interpersonal comparable (Ferrer-i-Carbonell and Frijters, 2004). Assuming cardinality means that the differences between life satisfaction rates are not dependent on the rate itself (i. e. the difference between rating 7 and rating 6 is the same as the difference between scores 3 and 2). In this context, empirical analysis can be done with OLS. Ordinal-interpersonal comparability means that when two respondents give the same answer, they are assumed to enjoy similar satisfaction levels. That is, "individuals have a common understanding of how to translate internal feelings into a number scale, so that numerical values from different individuals are roughly the same" (Ferrer-i-Carbonell and Frijters, 2004: 644). This requires the use of latent variable models, ordered probit or ordered logit, for the empirical analysis. Despite these differences, Ferrer-i-Carbonell and Frijters (2004) find that the assumption of cardinality or ordinality does not qualitatively change the results in the studies of happiness, and many papers rely on OLS estimates since their interpretation is more straightforward. ${ }^{7}$

A final comment on our dependent variable has to do with the fact that perceived pollution indicators at the workplace may be associated with life satisfaction, but also with job satisfaction. However, the channel through which workplace conditions, job satisfaction, and life satisfaction are related is difficult to ascertain. Thus, the causal relationship between job and life satisfaction is today subject to a lively debate in the social psychological literature (Bowling et al., 2010). ${ }^{8}$ In consequence, we do not look at job satisfaction separately from life satisfaction; rather, we consider that the final association between job environmental conditions and life satisfaction, no matter the channel, is captured in the specification used below.

Our variables of interest indicate each worker's self-perception regarding ventilation and noise at the workplace, ranging from 0 (very bad) to 10 (excellent). ${ }^{9}$ Regarding the income variable, net monthly income is provided in the survey by intervals. For estimation purposes, we use the mid-point approximation expressed in logs. ${ }^{10}$ Finally, $\mathrm{PM}_{10}$ is the set of particulate matter with a diameter of $10 \mu \mathrm{m}$ or less, emitted directly into

\footnotetext{
${ }^{7}$ In general terms, ordinal-interpersonal comparability is habitually assumed by economists, whereas cardinal-interpersonal comparability is rarely so (see $\mathrm{Ng}, 1997$, for an exception).

${ }^{8}$ The relative dearth of research in this line is far from achieving robust conclusions (Erdogan et al., 2012; Newman et al., 2015). In this context, considering job satisfaction in addition to life satisfaction would add possible sources of endogeneity.

${ }^{9}$ The question in the survey is "Please, evaluate the existing conditions in your workplace regarding air ventilation/noise". A higher rate means that the respondent considers that indoor conditions are better.

${ }^{10}$ We use this as the benchmark regression (acknowledging the suggestions made by anonymous referees). Results do not change when we estimate our models using income intervals. Results are available from the authors upon request.
} 
the atmosphere. It is basically composed by $\mathrm{NO}_{\mathrm{x}}, \mathrm{SO}_{2}, \mathrm{NH}_{3}$ and other particles resulting from domestic emissions from building and road construction, with transport contributing to impacts on health. The inhalation of such particles has harmful effects on human health and may increase the frequency and severity of a number of respiratory problems, which may, in turn, increase the risk of premature death. Along with ozone, these are Europe's most problematic pollutants in terms of harm to human health, according to the European Environmental Agency, EEA (2012). At the time of the survey, the air quality standard in European legislation (Directive 1999/30/EC) for long-term (annual) exposure places a limit of no more than 35 days per year that exceed a daily average concentration of 50 $\mu \mathrm{g} / \mathrm{m}^{3}$. Hence, we measure the $\mathrm{PM}_{10}$ variable as the number of days per year that average daily $\mathrm{PM}_{10}$ concentration exceeds $50 \mu \mathrm{g} / \mathrm{m}^{3}{ }^{31}$

\section{Empirical model}

We follow the standard approach, regressing SWB on a range of personal and job characteristics at the individual level, as well as relevant factors at the regional level, adding self-perceived variables of pollution at the workplace. To do this, we estimate the equation below, which combines individual and regional level information:

$$
L S_{i j t}=\alpha+\lambda_{t}+\tau_{j}+\beta_{0} X_{i j t}+\beta_{1} \ln Y_{i j t}+\gamma_{0} Z_{j t}+\gamma_{1} P M_{10 j t}+\delta_{1} V E N T_{i j t}+\delta_{2} N O I S E_{i j t}+\varepsilon_{i j t}
$$

where self-reported life satisfaction, LS, of individual $i$, in region $j$, in year $t$ depends on the year dummies $\left(\lambda_{t}\right)$, region dummies $\left(\tau_{j}\right)$, a vector of individual socio-demographic and job characteristics $\left(\mathrm{X}_{\mathrm{ijt}}\right)$, individual income $\left(\mathrm{Y}_{\mathrm{ijt}}\right)$, characteristics of the region where the individual resides (including annual per-capita GDP, unemployment rate, and indicators of climate, $\left.\mathrm{Z}_{\mathrm{jt}}\right)$, pollution $\left(\mathrm{PM}_{10}\right)$, and the subjective variables on ventilation and noise conditions at the workplace, VENT $_{\mathrm{ijt}}$ and $\mathrm{NOISE}_{\mathrm{ijt}}$.

Eq. (1) can be estimated by OLS or, given the ordinal nature of life satisfaction, by using either ordered probit or ordered logit models. A third possibility, as suggested by van Praag et al. (2003) and van Praag and Ferrer-i-Carbonell (2006, 2007) is to cardinalise the ordered responses into real-axis values, using Terza's (1987) methodology. This so-called Probit-OLS estimator (POLS, hereafter) is computationally

\footnotetext{
${ }^{11}$ Information is computed as the average $\mathrm{PM}_{10}$ measured in various nationally-scattered stations, we group into three levels according to population size of the area: urban (more than 100,000 inhabitants), suburban (between 10,000 and 100,000 inhabitants) and rural (less than 10,000 inhabitants). This information is matched to each individual in the sample so that individuals living in the same area, with a similar population size, share the same value of $\mathrm{PM}_{10}$. This approach is similar to that of Luechinger (2009) and MacKerron and Mourato (2009), who interpolate data captured from various stations through GIS techniques. In the case of Spain, Cuñado and Pérez-Gracia (2013) take average regional values from regional stations and claim that their constructed values correlate close to 1 with series constructed using GIS techniques.
} 
easier to implement than an ordered probit without any loss of efficiency. Results for OLS, ordered probit and POLS, are examined in detail in Section 5. As is usual in the empirical literature, we find little qualitative difference between the results of those approaches (see e.g., Ferrer-i-Carbonell and Frijters, 2004) and retain our OLS estimates, which are easier to interpret.

When estimating equation (1) we face certain difficulties. Thus, using self-reported measures of workplace environmental quality makes it possible that the perceived variables are affected by individual psychological characteristics, rather than reflecting objective environmental characteristics (Ferrer-i-Carbonell and Gowdy, 2007; MacKerron, 2012). That is, we are concerned about reverse causation, by which workplace pollution may generate a reduction in SWB, but also less satisfied individuals may become especially concerned and affected by workplace pollution. Not only SWB and self-perceived levels of pollution in the workplace are likely to be simultaneously determined, but also unobserved characteristics that are omitted from the equation are likely to affect both SWB and self-perceived levels of pollution in the workplace. Moreover, selection into jobs is likely to be non-random. Thus, happier individuals may be more likely to get better jobs, and these are likely to have better environmental conditions. This together suggests an endogeneity problem, leading to biased and inconsistent estimates of the causal effect of self-perceived noise levels on SWB. Since our data are repeated cross-sections, we cannot control for unobserved individual heterogeneity through panel data estimation. Therefore, we deal with it by implementing an instrumental variable strategy, which is now presented. ${ }^{12}$

We use a regional noise prevention reform as a source of exogenous variation in perceived noise. Specifically, we consider the noise prevention law, Law on Noise, that was passed in the Spanish region of Castile-Leon in 2009. This legislation presents a taxonomy of categories referring to acoustic emissions and noise pollution, and establishes maximum limits for each measure. It also sets up the corresponding sanctions when limits are exceeded. (A more detailed description can be found in Appendix B.) ${ }^{13}$ The application of this law makes possible the appearance of two different groups: the treatment group, corresponding to workers in Castile-Leon; and the control group,

\footnotetext{
${ }^{12}$ A cautionary note: in our dataset, there is no information, objective or subjective, about individual health status. Although this variable is customarily found to be much correlated with life satisfaction and happiness, many prior studies comparing estimates including and excluding health variables have shown that the estimated values for the rest of the covariates remain more or less unchanged, even if the health variables are statistically significant in determining happiness or life satisfaction (e.g., Levinson 2012; Ferreira et al., 2013).

${ }^{13} \mathrm{http}: / /$ noticias.juridicas.com/base_datos/CCAA/cl-15-2009.html. Law on Noise, 5/2009 Castile-Leon, $4^{\text {th }}$ of June 2009. The law was enforced August $9^{\text {th }}$ in that year.
} 
comprising workers in the rest of the Spanish regions. ${ }^{14}$ The IV estimation strategy consists of a two-stage estimation procedure, where the effect of the noise prevention reform for treated workers on self-perceived NOISE in the first-stage is used as an exclusion restriction.

$$
N O I S E_{i j t}=\pi_{0}+\phi_{t}+\varphi_{j}+\pi_{1} D D+\pi_{2} X_{i j t}+\pi_{3} \ln Y_{i j t}+\pi_{4} Z_{j t}+\pi_{5} P M_{10}+\pi_{6} V E N T_{i j t}+v_{1 j i t}
$$

where DD is a dummy variable that takes the value of 1 for the treatment group after the reform was implemented, and zero before implementation. The coefficient $\pi_{1}$ is interpreted as the increase in the rate of self-perceived noise attributable to the legal change in Castile-Leon, versus that of workers in the other regions. The standard identifying assumption is that the chosen instrumental variable is both relevant and validly excluded. The relevance condition requires that there is a strong correlation between this reform for the treatment group and the self-perceived noise variable $E[D D, N O I S E] \neq 0$. With respect to the validity condition, our assumption is that our instrument affects life satisfaction only through its effect on self-perceived noise but not directly $E\left[D D, v_{2 i j t}\right]=0$. In the second stage, the effect of self-perceived noise on worker life satisfaction is estimated based on specification (3) being captured by parameter $\delta_{2}$.

$$
L S_{i j t}=\alpha+\lambda_{t}+\tau_{j}+\beta_{0} X_{i j t}+\beta_{1} \ln Y_{i j t}+\gamma_{0} Z_{j t}+\gamma_{1} P M_{10}+\delta_{1} V E N T_{i j t}+\delta_{2} N \hat{O I S E_{i j t}}+v_{2 i j t}
$$

where predicted values of the variable NOISE, computed from equation (2), are plugged into equation (3) in order to give the IV estimates of the effects of self-perceived NOISE on life satisfaction. ${ }^{15}$ In order to assess the robustness of our approach, which uses a difference-in-difference strategy in the first stage, we follow a set of diagnostic tests outlined in Angrist and Pischke (2009). These include tests for the parallel trend assumption, the choice of control group, and several placebo tests.

The IV strategy is followed by a robustness check that attempts to reduce timeinvariant unobserved heterogeneity, employing a pseudo-panel approach. In order to do this, we separate the sample into homogeneous groups (cohorts). For our first cohort definition, we take a 5-year bracket of year of birth, where the first group includes those aged 26 and below, and the last group those aged 52 and over, and the same education level. Our second cohort definition is formed by a more aggregated age cohort and sector of industry. We construct sample means of the cohorts for each definition in order to

\footnotetext{
${ }^{14}$ Employees in Castile-Leon represent roughly 5\% of total employees in Spain. Employment in the Construction sector fell markedly during the Great Recession, declining from $12 \%$ in total employment in 2008 to less than 6\% in 2014 (9\% in 2010). This pattern was observed throughout the country.

${ }^{15}$ Equation (1) is estimated in Stata with the command ivreg2.
} 
form a panel structure of the data (Deaton, 1985; Blundell et al., 1994). These sample means act as proxies of the population means if the sample size is sufficiently large.

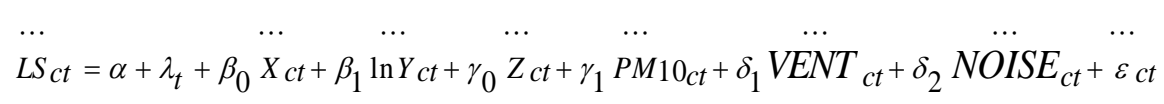

\section{Results}

We first present estimates without considering potential biases from endogeneity issues. OLS results under the assumption of cardinality of ordered variables are shown in Table 2. Table A1 in the Appendix presents the Ordered Probit estimates, obtained without imposing cardinality on our dependent variable, life satisfaction. Table A2 shows POLS estimates. In both cases, the ordered regressors capturing perceived pollution variables at the workplace are transformed into real values using Terza (1987).

\section{INSERT TABLE 2}

We consider four different specifications. The first includes all the regressors but the two variables capturing workplace environmental conditions. The second specification adds the variable of self-perceived ventilation at the workplace, with the third specification adding the variable of self-perceived noise at the workplace, and the fourth including both variables together. Tables $\mathrm{A} 1$ and $\mathrm{A} 2$ in the appendix follow the same structure. By comparing results in Tables 2, A1 and A2, it can be seen that results are qualitatively similar, as is commonly found in the empirical literature (Ferrer-i-Carbonell and Frijters, 2004). ${ }^{16}$ Consequently, in what follows, we refer to the OLS results that are the most straightforward to interpret. In all regressions, standard errors are clustered at the regional level to account for biases arising from different individuals living in the same region (Moulton, 1990). However, these results are robust to clustering standard errors at a region-year level.

The first important result is that workplace environmental variables are found to be statistically significant. Estimated results, in general, follow similar patterns observed in the empirical literature. ${ }^{17}$ Men are found to be more satisfied with their life than women. Age variables present the typical U-shape, indicating that, in the early years, satisfaction declines and then increases (with the minimum reached around age 50). Native workers are more satisfied than foreign workers. A higher educational level is associated with greater life satisfaction. The family structure and the need to balance family and work responsibilities are found to be important elements in shaping life satisfaction. Thus,

\footnotetext{
${ }^{16}$ Ordered Probit and POLS estimates are equivalent, except for a proportionality factor, as argued by van Praag and Ferrer-i-Carbonell (2006).

${ }^{17}$ Our results are robust to include region-year specific fixed effects.
} 
being married is associated with greater satisfaction, but a larger family size, taking care of dependents, or the existence of only one earner in the household, all lead to lower life satisfaction.

Regarding the work-related variables, we note that most of the results are as expected. Higher income is positively associated with greater life satisfaction, as is working in the public sector. We introduce the number of weekly hours worked via a range of dummy variables. Taking the typical 35-40 hours per week as reference, working fewer hours is associated with greater life satisfaction, whereas working more than 45 hours results in less satisfaction. Labour stability leads to increases in life satisfaction whereas tenure and being in the first job do not appear to be significant. By contrast, over-education strongly reduces the level of life satisfaction. A non-split workday has no significant relationship with life satisfaction, whereas a night-shift reduces it. Firm size associated with the highest level of life satisfaction corresponds to that of 51-250 workers. Workers in agriculture are least satisfied, followed by workers in the service sector. In sum, we find that life satisfaction increases with certain personal and job characteristics, the most important being: married, higher income, working in a job matching the educational level attained, and holding a permanent contract.

Regarding regional variables, only maximum temperature in July is statistically significant, having a negative relationship with life satisfaction. GDP, unemployment rate, and the other two climate variables, minimum temperature in January and mean annual precipitation, are not statistically significant. The environmental variable, $\mathrm{PM}_{10}$, is significant at the $1 \%$ level. The observed negative effect is in line with the evidence found in Cuñado and Perez-Gracia (2013), Levinson (2012), and Menz and Welsch (2010).

Focusing now on variables capturing workplace environmental conditions, our estimated coefficients are positive and significant, showing that a higher score on conditions at the workplace in air ventilation and noise are both conducive to greater life satisfaction. These results are as expected in light of prior studies (Wargocki et al., 2012). The inclusion of these two variables barely affects the other covariates' estimated coefficients, confirming that including indicators of environmental conditions at the workplace is very useful in obtaining a better understanding of the determinants affecting satisfaction. If greater life satisfaction spurs effort and productivity, and reduces absenteeism, personnel policies favouring better conditions in the workplace may result in clear improvements in job performance, and eventually in higher profits. 
Table 3 shows our IV estimation where only the coefficients of the variables of interest are shown to save space. The first stage results in the upper panel indicate that workers in Castile-Leon improved their perception of noise conditions at the workplace by 3.6216 points on the scale (SE 1.0848), relative to that of workers in the rest of the Spanish regions, due to the noise reform introduced by the government of Castile-Leon in 2009. The IV estimate in the lower panel is 0.0368 (SE 0.0127), which is larger than the OLS-estimated regression coefficient of 0.0247 (SE 0.0033), indicating that some of the bias from reverse causation or unobserved variables (affecting both life satisfaction and self-perceived noise conditions at the workplace) is corrected. The IV-estimated regression coefficient can have a Local Average Treatment Effect interpretation, that is, it can be interpreted as the effect of self-perceived noise levels on the life satisfaction of those workers impacted by the noise reforms that took place in Castile-Leon.

\section{INSERT TABLE 4}

Table 4 shows additional procedures to demonstrate the robustness of our results to standard concerns derived from applying a difference-in-difference methodology as an instrument: (i) violations of the common trend assumption; (ii) the suitability of the control group; and (iii) placebo policy tests. Table 4 shows the first-stage, when we allow for differential trends in self-perceived noise levels between the treatment and the control group. The interaction term between the treatment group (Castile-Leon) and the year trend is not statistically significant, and the DD estimate remains essentially unchanged (3.6496; SE 1.4778). This suggests that the trends of noise-levels are parallel, pretreatment, in the immediate pre-reform period.

A more general concern is whether workers in the rest of the Spanish regions provide a good counter-factual for workers in Castile-Leon. Nonetheless, we investigate this further using a synthetic control method, following Abadie and Gardeazabal (2003). This method consists of comparing the noise level series of the treatment group (Castile-Leon) with a synthetic noise level series for the control group (the rest of the Spanish regions) in a straightforward difference-in-difference. To do this, we allow the data to determine a synthetic control that optimally weights the various regions in the control group to match the underlying characteristics of the treated group (Castile-Leon), pre-policy. The matching minimises the mean squared prediction error for the pre-policy periods. ${ }^{18}$ The resulting estimates are very similar (3.666; SE 1.620), although this does entail a loss of precision.

\footnotetext{
${ }^{18}$ The optimal weight method gives a weight of 1 to the region of La Rioja.
} 
We then conduct a battery of placebo policy tests. The same regression (3) is estimated in order to observe the effect of the reform for the treated group on the selfperceived air ventilation variable, rather than that of noise. Workers in our treatment group do not appear to be significantly affected by the reform, relative to workers in the rest of the Spanish regions. Moreover, we consider that our reform occurred in previous periods ( $\mathrm{t}-1$ and $\mathrm{t}-2)$ as a form of placebo policy test. This placebo DD is not statistically different from zero.

\section{INSERT TABLE 5}

As an additional check, Table A.3 presents pseudo-panel estimates of the effect of outdoor and indoor workplace environmental conditions on life satisfaction. We have constructed two different definitions of cohort: the first considers that a worker belongs to the same cohort if the age group and education level is the same ( 7 age groups times 3 education groups) and, thus, comprises 21 different cohorts, leading to 105 observations. The second considers that a worker belongs to the same cohort if the age group and classification of industry is the same ( 3 age groups, times 10 different industry sectors). The point estimates are very similar to those obtained using individual data. Most importantly, when we take into account time-invariant, unobserved heterogeneity using cohort fixed-effects estimations, there remains a positive and significant effect of selfperceived ventilation and noise levels on life satisfaction.

A final exercise is the monetary valuation of non-market goods: pollution variable and environmental conditions at the workplace, as well as a direct comparison between both magnitudes. Under the assumption that reported life satisfaction can serve as a measure of individual utility (Kahneman et al., 1997), we can derive the average marginal rate of substitution (MRS) between income and general air quality, and between income and environmental conditions in the workplace, thereby capturing the marginal willingness-to-pay (WTP) for a specific attribute.

$$
M R S_{\mathrm{PM}_{10}}^{Y}=-\frac{\partial L S / \partial \mathrm{PM}_{10}}{\partial L S / \partial Y}=-\frac{\gamma_{1}}{\beta_{1}} Y \quad M R S_{\Sigma}^{Y}=\frac{\partial L S / \partial \Sigma}{\partial L S / \partial Y}=\frac{\delta_{h}}{\beta_{1}} Y
$$

where $\Sigma=$ VENT, NOISE and $\mathrm{h}=1,2$.

Table 5 shows the WTP for each of the environmental attributes computed from estimates in Table 3. An individual is willing to pay, on average, between $€ 17$ and $€ 20$ per year to reduce by one the number of days with an excess of $\mathrm{PM}_{10}$. These monetary valuations are lower than those found elsewhere. ${ }^{19}$ Regarding the environmental

${ }^{19}$ Using the same approach for Spain, Cuñado and Pérez-Gracia (2013) obtain a value of €325 per year. Other studies compute the MWTP as a reduction by one unit of the annual average concentration of $\mathrm{PM}_{10}$. For the US, Levinson (2012) finds a value of \$890; for Ireland, Ferreira and Moro (2010) €945, and Menz 
attributes in the workplace, the marginal rate of substitution measures the willingness to pay for moving from one category to the next higher. Thus, an employee is willing to pay on average $€ 530$ per year for a one-point improvement in air ventilation in the workplace, ${ }^{20}$ and around $€ 1,800$ per year in the case of the self-perceived noise scale. ${ }^{21}$ These numbers represent, respectively, $3.5 \%$ and $12.5 \%$ of the average annual income. Standard errors of the WTP are calculated using the delta method.

As a matter of comparison, Van Praag and Baarsma (2005) use both objective and subjective indicators of noise nuisance for individuals living close to Schiphol airport in Amsterdam. As an average value, about $€ 400$ per year - depending on distance to airport, noise nuisance level, family income, and dwelling insulation - would be needed to compensate individuals for increasing the level of noise nuisance. These figures are clearly lower than our estimated monetary values. By contrast, the only study that uses subjective indicators of air and noise pollution (in the individual's residential area) is Rehdanz \& Maddison (2008). Their results, based on hedonic price valuations, show that about $€ 690$ per household per month ( $€ 8,280$ per year) would be needed to compensate for a reduction from one category to the next lower in air pollution $(€ 390$ per month, $€ 4,680$ per year, in the case of noise exposure). ${ }^{22}$ These values are comparably similar to ours, given that their ordered variables are expressed on a 5-point scale and that the information provided is on household income. Overall, although outdoor and indoor values are not directly comparable, since they are measured in different units, it appears that employees are less reluctant to pay for improving conditions in the workplace.

\section{Conclusions}

There is an ample literature showing that SWB does not depend exclusively on income, but on a wide range of factors. Among these factors, concerns about outdoor environmental conditions have progressively increased in recent years, although there remains a lack of evidence on how well-being is related to indoor environmental conditions. This paper expands the research on SWB and outdoor environmental conditions by considering environmental conditions indoors. Specifically, we examine the impact of self-perceived levels of air and noise pollution in the workplace, on life

and Welsch (2010), for a cross-country study within the OECD, \$710. Translating the results by Levinson (2012) into our measure, he obtains a valuation of $\$ 63$ when reducing by one day the level of $\mathrm{PM}_{10}$ in 50 $\mu \mathrm{g} / \mathrm{m}^{3}$.

${ }^{20}$ Note that self-perceived air ventilation is not instrumented and therefore estimates are likely to be biased.

${ }^{21}$ Note that, in the way these variables are measured, a higher rate is associated with better workplace conditions. Therefore, in order to obtain the MWTP of an individual, he/she needs to pay for an improvement in workplace conditions to remain at the same utility level. This is the reason for the positive sign in the second expression of specification (5), as against the case in the first expression.

${ }^{22}$ In a scale ranging from not being affected by noise at all to being strongly affected. 
satisfaction. Our results demonstrate that poor air ventilation and high noise levels in the workplace markedly diminish life satisfaction, with variables capturing environmental pollution outdoors also showing a negative relationship to life satisfaction. This confirms the need to consider indicators of environmental conditions both outdoors and indoors, in order to obtain a more realistic view of how well-being is associated with life quality.

Our results hold even after controlling for endogeneity arising from reverse causation or unobserved heterogeneity, by using an instrumental variable strategy. Our IV estimates are clearly different from our OLS results. When estimating the effect on life satisfaction of individual self-perceived noise levels in the workplace, some of the bias is corrected when we use a noise prevention law to generate exogenous variation in self-perceived noise pollution. The results appear to be robust to controlling for violations in the common trends assumption and to the choice of the control group.

Additionally, we provide a monetary valuation of environmental conditions, both outdoors and indoors, using the life satisfaction approach. An individual is willing to pay about $€ 20$ per year to reduce, by one, the number of days with an excess of $\mathrm{PM}_{10}$ concentrations. The WTP for a one-point improvement in air ventilation and in noise levels in the workplace is much higher, around $€ 530$ and $€ 1,800$ per year, respectively. Since outdoor environmental conditions are measured through objective indicators, and indoor environmental conditions are expressed in subjective terms, we cannot make direct comparisons of the large differences observed in both types of valuation. The main conclusion we draw is that individuals would be better off if all environmental conditions were improved.

Even if both types of pollution (outdoors and indoors) do have an impact on individual wellbeing, the implications of such self-perceptions for future policy applications may be very different. Although reducing pollution would result in an increase in SWB for individuals, it may also generate additional costs to firms, if satisfying regulatory norms and legislation on the matter implies efficiency losses. However, in the case of outdoor pollution, the additional costs borne by firms are understood as a way to internalize negative externalities; in the case of indoor pollution, the possible increase in firm costs due to improvements in workplace environmental conditions may be counterbalanced by higher profits through workers' greater productivity as a consequence of greater effort, lower absenteeism and turnover, and absence of conflict with unions. From the point of view of a cost-benefit analysis, it may be the case that improving working conditions is a rational decision for firms, to become more efficient, even if laws are not so restrictive. 


\section{Acknowledgments}

The authors would like to thank three anonymous referees and the editor Richard B. Howarth for helpful comments. Financial support from the Autonomous Government of Aragón (Consolidated Research Group S13) is gratefully acknowledged.

\section{Appendix A}

\section{INSERT TABLES A.1, A.2, A.3}

\section{Appendix B}

The regulatory framework of the Law on Noise, 5/2009 Castile-Leon, originates from several EU directives aimed at reducing noise emissions, such as Directive 2002/49/EC of the European Parliament and of the Council of 25 June 2002, relating to the assessment and management of environmental noise, among other factors. This Directive establishes common assessment methods for "environmental noise" and a definition for "limit values", in terms of harmonised indicators for the determination of noise levels. This directive was incorporated into the Spanish law by Law 37/2003 of November 17 on Noise. The autonomous communities may exercise jurisdiction in developing basic legislation on the environment, and in this context the law passed with the aim of becoming essential in preventing, reducing and monitoring noise pollution in the autonomous community of Castile-Leon.

The law consists of 4 titles, 11 additional provisions, 7 transitory provisions and 9 annexes. Title I defines the purpose and scope of the law. Title II classifies acoustic factors in indoor and outdoor areas, classifying, in turn, from silent areas to particularly noisy areas, setting the acoustic quality objectives for each. Acoustic indices are proposed and limit values are defined for noise emissions. Similarly, the minimum values for acoustic insulation are determined. Entities of Acoustic Evaluation are regulated and the production of noise maps is contemplated. Title III is dedicated to the prevention and correction of noise pollution, declaring noise control as a mandatory service provision. Acoustic control of the building is regulated and control measures of activities emitting acoustic sets are established. In addition, action plans aiming to review and correct noise pollution are to follow. Title IV is devoted to inspection and sanctions. Limit values on sound produced by acoustic and environmental issuers, acoustic insulation of activities, vibration limits, and methods of evaluation are listed in the Annexes.

Overall, the aim of the law is to avoid, prevent, or reduce the harmful effects, including annoyance, due to exposure to environmental indoor and outdoor noise 
pollution, and to preserve environmental noise quality where it is already at an acceptable level.

\section{References}

Abadie, A., and Gardeazabal, J., 2003. The economic costs of conflict: a case study of the Basque Country. American Economic Review 93, 113-132.

Angrist, J. D., and Pischke, J., 2009. Mostly Harmless Econometrics: An Empiricist's Companion. Princeton University Press. New Yersey.

Blanchflower, D. G., Oswald, A. J., 2008. Hypertension and happiness across nations. Journal of Health Economics 27(2), 218-233.

Blundell, R., Browning, M., Meghir, C., 1994. Consumer Demand and the Life-Cycle Allocation of Household Expenditures. Review of Economic Studies 61, 57-80.

Bowling, N., Escheman, K., Wang, Q., 2010. A meta-analytic examination of the relationship between job satisfaction and subjective well-being. Journal of Occupational and Organizational Psychology 83, 915-934.

Brereton, F., Clinch, J.P., Ferreira, S., 2008. Happiness, geography and the environment. Ecological Economics 65, 386-396.

Bruni, L., Porta, P. L., 2007. Handbook on the economics of happiness. Northampton, MA: Edward Elgar.

Carr, J.Z., Schmidt, A.M., Ford, J.K., DeShon, R.P., 2003. Climate perceptions matter: A meta-analytic path analysis relating molar climate, cognitive and affective states, and individual level work outcomes. Journal of Applied Psychology 88(4), 605-619.

Carrol, N., Frijters, P., Shields, M. A., 2009. Quantifying the cost of drought: New evidence from life satisfaction data. Journal of Population Economics 22, 445-461.

Clark, A.E., Oswald, A., 1994. Unhappiness and unemployment. The Economic Journal 104, 648-659.

Cuñado, J., Pérez-Gracia, F., 2012. Does education affect happiness? Evidence for Spain. Social Indicators Research 108(1), 185-196.

Cuñado, J., Pérez-Gracia, F., 2013. Environment and happiness: New evidence for Spain. Social Indicator Research 112 (3), 549-567.

Deaton, A., 1985. Panel data from time series of cross-sections. Journal of Econometrics 30, 109-126.

Di Tella, R., MacCulloch, R. J., 2006. Some uses of happiness data in economics. Journal of Economic Perspectives 20, 25-46. 
Di Tella, R., MacCulloch, R. J., Oswald, A. J., 2001. Preferences over inflation and unemployment: Evidence from surveys of happiness. American Economic Review 91, $335-341$.

Di Tella, R., MacCulloch, R.J., 2008. Gross national happiness as an answer to the Easterlin paradox. Journal of Development Economics 86 (1), 22-42.

Diener E., Suh E. M., Lucas R. E., Smith H. L., 1999. Subjective well-being: three decades of progress. Psychological Bulletin 125, 276-302.

Dolan, P., Peasgood, T., White, M., 2008. Do we really know what makes us happy? A review of the economic literature on the factors associated with subjective well-being. Journal of Economic Psychology 29, 94-122.

Easterlin, R., 1974. Does economic growth improve the human lot? Some empirical evidence. In P.A. David and M.W. Reder (eds), Nations and Households in Economic Growth: Essays in Honour of Moses Abramovitz. New York: Academic Press, pp. 89125.

EEA 2012. Air quality in Europe EEA Report No 4/2012. European Environmental Agency, Copenhaghen 2012.

Erdogan, B., Bauer, T., Truxillo, D., Mansfield, L., 2012. Whistle while you work: a review of the life satisfaction literature. Journal of Management 39(4), 1038-1083.

Ferreira, S. Moro, M., 2010. On the use of subjective well-being data for environmental valuation. Environmental and Resource Economics 46(3), 249-273.

Ferreira, S., Moro, M., Clinch, J. P., 2006. Valuing the environment using the lifesatisfaction approach. Planning and Environmental Policy Research Series Working Paper, School of Geography, University College Dublin.

Ferreira, S., Akay, A., Brereton, F., Cuñado, J., Martinsson, P., Moro, M., Ningal, T. F., 2013. Life satisfaction and air quality in Europe. Ecological Economics 88, 1-10.

Ferrer-i-Carbonell, A., 2013. Happiness economics. Series-Journal of the Spanish Economic Association 4(1), 35-60.

Ferrer-i-Carbonell, A., Frijters, P., 2004. How important is methodology for the estimates of the determinants of happiness? The Economic Journal 114 (497), 641-659.

Ferrer-i-Carbonell, A., Gowdy, J.M., 2007. Environmental degradation and happiness? Ecological Economics 60 (3), 509-516.

Frey, B. S., Luechinger, S., Stutzer, A., 2010. The life satisfaction approach to environmental valuation. Annual Review of Resource Economics 2(1), 139-160.

Frey, B.S., Stutzer, A., 2002. Happiness and Economics. University Press, Princeton. 
Frijters, P., van Praag, B., 1998. The effect of climate on welfare and well-being in Russia. Climate Change 39, 61-81.

Frontzak, M.J., Wargocki, P., 2011. Literature survey on how different factors influence human comfort in indoor environments. Building and Environment 46 (4), 922-937.

Gupta, N. D., Kristensen, N., 2008. Work environment satisfaction and employee health: panel evidence from Denmark, France and Spain, 1994-2001. The European Journal of Health Economics 9(1), 51-61.

Kahnenman, D., Diener, E., Schwarz, N., 1999. Foundations of Hedonic Psychology: Scientific Perspectives on Enjoyment and Suffering, New York: Russel Sage Foundation.

Kahneman, D., Krueger, A.B., 2006. Developments in the measurement of subjective well-being. Journal of Economic Perspectives 20 (1), 3-24.

Kahnenman, D., Wakker, P.P., Sarin, R., 1997. Back to Bentham? Explorations of experienced utility. The Quarterly Journal of Economics 112 (2), 375-405.

Levinson, A., 2012. Valuing public goods using happiness data: the case of air quality. Journal of Public Economics 96 (9-10), 869-880.

Luechinger, S., 2009. Valuing air quality using the life satisfaction approach. The Economic Journal 119, 482-515.

Luechinger, S., 2010. Life satisfaction and transboundary air pollution. Economics Letters 107 (1), 4-6.

Luechinger, S., Raschky, P., 2009. Valuing flood disasters using the life satisfaction approach. Journal of Public Economics 93, 620-633.

MacKerron, G., 2012. Happiness economics from 35000 feet. Journal of Economic Surveys 26 (4), 705-735.

MacKerron, G., Mourato, S., 2009. Life satisfaction and air quality in London. Ecological Economics 68 (5), 1441-1453.

McCaughey, D., McGhan, G., Walsh, E.M., Rathert, C., Belue, R., 2014. The relationship of positive work environments and workplace injury: Evidence from the National Nursing Assistant Survey. Health Care Manage Review 39(1), 75-88.

Menz, T., Welsch, H., 2010. Population aging and environmental preferences in OECD countries: The case of air pollution. Ecological Economics 69(12), 2582-2589,

Moulton, B.R., 1990. An illustration of a pitfall in estimating the effects of aggregate variables on micro unit. The Review of Economics and Statistics 72 (2), 334-338. 
Murray, T., Maddison, D., Rehdanz, K., 2013. Do geographical variations in climate influence life-satisfaction? Climate Change Economics 4 (1), 1350004 DOI: 10.1142/S2010007813500048.

Newman, A., Nielsen, I., Smyth, R., Hooke, A., 2015. Examining the relationship between workplace support and life satisfaction: the mediating role of job satisfaction. Social Indicators Research 120, 769-781.

Ng, Y., 1997. A case for happiness, cardinalism, and interpersonal comparability. Economic Journal 107 (445), 1848-1858.

Oswald, A. J., 1997. Happiness and economic performance. Economic Journal 107, 1815-1831.

Parker, C.P., Baltes, B.B., Young, S.A., Huff, J.W., Altmann, R.A., Lacost, H.A. , Roberts, J.E., 2003. Relationships between psychological climate perceptions and work outcomes: A meta-analityc review. Journal of Organizational Behavior 24 (4), $389-416$.

Rehdanz, K., Maddison, D., 2005. Climate and happiness. Ecological Economics 52, $111-125$.

Rehdanz, K., Maddison, D., 2008. Local environmental quality and life-satisfaction in Germany. Ecological Economics 64 (4), 787-797.

Terza, J. V., 1987. Estimating linear models with ordinal qualitative regressors. Journal of Econometrics 34(3), 275-291.

Van Praag, B.M.S., Baarsma, B.E., 2005. Using happiness surveys to value intangibles: the case of airport noise. The Economic Journal 115, 224-246.

Van Praag, B. M. S., Frijters, P., Ferrer-i-Carbonell, A., 2003. The anatomy of subjective well-being. Journal of Economic Behavior \& Organization 51(1), 29-49.

Van Praag, B. M. S., Ferrer-i-Carbonell, A., 2006. An almost integration-free approach to ordered response models. TI 2006-047/3, Tinbergen Institute Discussion Paper, Amsterdam.

Van Praag, B. M. S., Ferrer-i-Carbonell, A., 2007. Happiness Quantified: A Satisfaction Calculus Approach, OUP Catalogue, Oxford University Press, number 9780199226146.

Wargocki, P., Frontczak, M., Schiavon, S., Goins, J., Arens, E., Zhang, H., 2012. Quantitative relationship between occupant satisfaction and satisfaction aspects of indoor environmental quality and building design. Indoor Air, 22(2), 119-131.

Welsch, H., 2002. Preferences over prosperity and pollution: environmental valuation based on happiness surveys. Kyklos 55, 473-494. 
Welsch, H., 2003. Freedom and rationality as predictors of cross-national happiness patterns. Journal of Happiness Studies 4, 295-321.

Welsch, H., 2006. Environment and happiness: valuation of air pollution using life satisfaction data. Ecological Economics 58, 801-813.

Welsch, H., 2007. Environmental welfare analysis: a life satisfaction approach. Ecological Economics 62, 544-551.

Welsch, H., 2009. Implications of happiness research for environmental economics. Ecological Economics 68, 2735-2742.

Welsch, H., Ferreira, S., 2014. Environment, well-being and experienced preference. International Review of Environmental and Resource Economics 7, 205-239.

Welsch, H., Kühling, J., 2009. Using happiness data for environmental valuation: issues and applications. Journal of Economic Surveys 23, 385-406. 
Table 1. Variable definitions and descriptive statistics

\begin{tabular}{|c|c|c|c|c|c|}
\hline Variable & Definition & Mean & St. Dev. & Min. & Max. \\
\hline Life satisfaction & $\begin{array}{l}\text { Satisfaction with personal life (0: not satisfied, } \\
\text { 10: very satisfied) }\end{array}$ & 7.52 & 1.84 & 0 & 10 \\
\hline \multicolumn{6}{|c|}{ Personal characteristics } \\
\hline Male & 1: Male, 0: Female & 0.55 & 0.49 & 0 & 1 \\
\hline Age & Age in years & 41.29 & 10.79 & 16 & 90 \\
\hline $\mathrm{Age}^{2} / 100$ & Age squared divided by 100 & 18.21 & 9.07 & 2.56 & 81 \\
\hline Spanish & 1: Spanish, 0: foreign & 0.89 & 0.31 & 0 & 1 \\
\hline Compulsory & Compulsory education & 0.39 & 0.49 & 0 & 1 \\
\hline Post-compulsory & Post-compulsory secondary education & 0.34 & 0.47 & 0 & 1 \\
\hline Higher & Higher Education & 0.27 & 0.44 & 0 & 1 \\
\hline Married & 1: Married, 0: Otherwise & 0.65 & 0.47 & 0 & 1 \\
\hline Family size & Number of family members & 3.10 & 1.17 & 1 & 6 \\
\hline Care & $\begin{array}{l}\text { 1: Taking care of children or elderly people; } 0 \text { : } \\
\text { Otherwise } \\
1: \text { He/she is the only income earner in the family; }\end{array}$ & 0.06 & 0.24 & 0 & 1 \\
\hline $\begin{array}{l}\text { Single-earner } \\
\text { Job characteristics }\end{array}$ & 0 : Otherwise & 0.50 & 0.50 & 0 & 1 \\
\hline Log income & Log of the mid-income interval & 7.09 & 0.46 & 6.21 & 8.85 \\
\hline Public sector & 1: public sector; 0: private sector & 0.25 & 0.43 & 0 & 1 \\
\hline Hours $\leq 25$ & Up to 25 hours worked per week & 0.09 & 0.28 & 0 & 1 \\
\hline Hours 26-35 & Between 26 and 35 hours worked per week & 0.15 & 0.35 & 0 & 1 \\
\hline Hours 36-40 & Between 36 and 40 hours worked per week & 0.53 & 0.50 & 0 & 1 \\
\hline Hours 41-45 & Between 41 and 45 hours worked per week & 0.09 & 0.29 & 0 & 1 \\
\hline Hours $>45$ & More than 45 hours worked per week & 0.13 & 0.34 & 0 & 1 \\
\hline Permanent & Permanent contract: 1 , fixed-term contract: 0 & 0.77 & 0.42 & 0 & 1 \\
\hline Tenure $<1$ & Tenure less than 1 year & 0.13 & 0.34 & 0 & 1 \\
\hline Tenure $1-5$ & Tenure between 1 and 5 years & 0.32 & 0.47 & 0 & 1 \\
\hline Tenure 6-10 & Tenure between 6 and 10 years & 0.18 & 0.38 & 0 & 1 \\
\hline Tenure $>10$ & Tenure longer than 10 years & 0.36 & 0.48 & 0 & 1 \\
\hline First job & 1: This is the first job & 0.23 & 0.42 & 0 & 1 \\
\hline Over-education & 1: higher-than-required qualification & 0.19 & 0.39 & 0 & 1 \\
\hline Workday & Non-split workday: 1; split workday: 0 & 0.58 & 0.49 & 0 & 1 \\
\hline Night shift & $\begin{array}{l}\text { Work more than three hours, or at least one third } \\
\text { of the year workload, is between } 10 \mathrm{pm} \text { and } 6 \text { am }\end{array}$ & 0.14 & 0.35 & 0 & 1 \\
\hline Firm size $1-10$ & Firm size lower than 10 employees & 0.35 & 0.47 & 0 & 1 \\
\hline Firm size $11-50$ & Firm size between 11 and 50 employees & 0.31 & 0.46 & 0 & 1 \\
\hline Firm size $51-250$ & Firm size between 51 and 250 employees & 0.17 & 0.37 & 0 & 1 \\
\hline Firm size $>250$ & Firm size higher than 250 employees & 0.12 & 0.33 & 0 & 1 \\
\hline Agriculture & Dummy 0-1 & 0.03 & 0.16 & 0 & 1 \\
\hline Industry & Dummy 0-1 & 0.18 & 0.38 & 0 & 1 \\
\hline Construction & Dummy 0-1 & 0.10 & 0.30 & 0 & 1 \\
\hline Services & Dummy 0-1 & 0.69 & 0.46 & 0 & 1 \\
\hline \multicolumn{6}{|l|}{ Regional } \\
\hline GDP & $\begin{array}{l}\text { Gross Domestic Product per capita, by region } \\
\text { and year (in euros) }\end{array}$ & $24,150.4$ & $4,479.24$ & 15,156 & 31,791 \\
\hline Unemployment rate & Unemployment rate by region and year & 12.42 & 5.85 & 4.8 & 28.89 \\
\hline January min temp. & $\begin{array}{l}\text { Mean of daily min. temperature in January }\left({ }^{\circ} \mathrm{C}\right) \\
\text { by region and year }\end{array}$ & -1.66 & 3.76 & -9.8 & 13.25 \\
\hline July max temperature & $\begin{array}{l}\text { Mean of daily max. temperature in July }\left({ }^{\circ} \mathrm{C}\right) \text { by } \\
\text { region and year }\end{array}$ & 35.77 & 3.35 & 24.3 & 45 \\
\hline $\begin{array}{l}\text { Mean annual } \\
\text { precipitation }\end{array}$ & Annual mean precipitation (mm) & 575.62 & 274.06 & 128.4 & 1537.2 \\
\hline
\end{tabular}


Number of days per year that average daily $\mathrm{PM}_{10}$ concentration exceeds $50 \mu \mathrm{g} / \mathrm{m}^{3}$, per region,

$\mathrm{PM}_{10}$ residence area, and year.

Self-evaluation of air quality at job (0 vary bad10 excellent).

Self-evaluation of acoustic comfort at job (0 vary bad-10 excellent). $\begin{array}{llll}28.14 & 48.41 & 0 & 209\end{array}$

$\begin{array}{llll}6.78 & 3.10 & 0 & 10\end{array}$

$\begin{array}{llll}6.11 & 3.10 & 0 & 10\end{array}$

ECVT stands for Quality of Working Life Survey 2006-2010

(http://www.empleo.gob.es/estadisticas/ecvt/welcome.htm); AEMET stands for Spanish National Meteorological Agency (http://www.aemet.es/es/portada) and MAFE stands for the Spanish Ministry of Agriculture, Food and Environment (http://www.magrama.gob.es). Regions are defined at the NUTS2 level (17 regions) and occupations are 10 main groups of ISCO-88 classification. 
Table 2. Effect of outdoor and indoor environmental conditions on life satisfaction (OLS)

\begin{tabular}{|c|c|c|c|c|}
\hline & $(1)$ & $(2)$ & (3) & (4) \\
\hline Male & $\begin{array}{c}0.0895^{* *} \\
(0.0369)\end{array}$ & $\begin{array}{c}0.0890 * * \\
(0.0379)\end{array}$ & $\begin{array}{c}0.0920 * * \\
(0.0362)\end{array}$ & $\begin{array}{c}0.0875 * * \\
(0.0380)\end{array}$ \\
\hline Age & $\begin{array}{c}-0.0960 * * * \\
(0.0071)\end{array}$ & $\begin{array}{c}-0.0943 * * * \\
(0.0082)\end{array}$ & $\begin{array}{c}-0.0957 * * * \\
(0.0066)\end{array}$ & $\begin{array}{c}-0.0939 * * * * \\
(0.0081)\end{array}$ \\
\hline $\mathrm{Age}^{2} / 100$ & $\begin{array}{c}0.0984 * * * \\
(0.0083)\end{array}$ & $\begin{array}{c}0.0945 * * * \\
(0.0093)\end{array}$ & $\begin{array}{c}0.0974 * * * \\
(0.0076)\end{array}$ & $\begin{array}{c}0.0939 * * * \\
(0.0092)\end{array}$ \\
\hline Spanish & $\begin{array}{c}0.3765 * * * \\
(0.0447)\end{array}$ & $\begin{array}{c}0.3572 * * * \\
(0.0465)\end{array}$ & $\begin{array}{c}0.3829 * * * \\
(0.0454)\end{array}$ & $\begin{array}{c}0.3595 * * * \\
(0.0482)\end{array}$ \\
\hline Post-compulsory & $\begin{array}{c}0.0695^{* *} \\
(0.0303)\end{array}$ & $\begin{array}{c}0.0643 * \\
(0.0352)\end{array}$ & $\begin{array}{c}0.0666^{*} \\
(0.0317)\end{array}$ & $\begin{array}{c}0.0623 * \\
(0.0341)\end{array}$ \\
\hline Higher & $\begin{array}{c}0.1146 * * * \\
(0.0298)\end{array}$ & $\begin{array}{c}0.1237 * * * \\
(0.0379)\end{array}$ & $\begin{array}{c}0.1171 * * * \\
(0.0317)\end{array}$ & $\begin{array}{c}0.1193 * * * \\
(0.0360)\end{array}$ \\
\hline Married & $\begin{array}{c}0.6277 * * * \\
(0.0284)\end{array}$ & $\begin{array}{c}0.6166 * * * \\
(0.0216)\end{array}$ & $\begin{array}{c}0.6316 * * * \\
(0.0262)\end{array}$ & $\begin{array}{c}0.6181 * * * \\
(0.0218)\end{array}$ \\
\hline Family size & $\begin{array}{c}-0.0495 * * * \\
(0.0104)\end{array}$ & $\begin{array}{c}-0.0542 * * * \\
(0.0100)\end{array}$ & $\begin{array}{c}-0.0494 * * * \\
(0.0103)\end{array}$ & $\begin{array}{c}-0.0548 * * * * \\
(0.0100)\end{array}$ \\
\hline Care & $\begin{array}{c}-0.2883 * * * \\
(0.0260)\end{array}$ & $\begin{array}{c}-0.2736 * * * \\
(0.0299)\end{array}$ & $\begin{array}{c}-0.2824 * * * \\
(0.0269)\end{array}$ & $\begin{array}{c}-0.2698 * * * \\
(0.0304)\end{array}$ \\
\hline Single-earner & $\begin{array}{c}-0.1938 * * * \\
(0.0161)\end{array}$ & $\begin{array}{c}-0.1976 * * * \\
(0.0162)\end{array}$ & $\begin{array}{c}-0.1945^{* * *} * \\
(0.0188)\end{array}$ & $\begin{array}{c}-0.1990 * * * * \\
(0.0168)\end{array}$ \\
\hline Log income & $\begin{array}{c}0.2963 * * * \\
(0.0240)\end{array}$ & $\begin{array}{c}0.2356 * * * \\
(0.0256)\end{array}$ & $\begin{array}{c}0.2826 * * * \\
(0.0240)\end{array}$ & $\begin{array}{c}0.2344 * * * \\
(0.0254)\end{array}$ \\
\hline Public sector & $\begin{array}{c}0.0680 * * \\
(0.0289)\end{array}$ & $\begin{array}{c}0.0999 * * * \\
(0.0310)\end{array}$ & $\begin{array}{c}0.0742 * * \\
(0.0270)\end{array}$ & $\begin{array}{c}0.1009 * * * \\
(0.0311)\end{array}$ \\
\hline Hours $\leq 25$ & $\begin{array}{c}0.1625^{* *} * \\
(0.0573)\end{array}$ & $\begin{array}{c}0.1301 * * \\
(0.0588)\end{array}$ & $\begin{array}{c}0.1609 * * * \\
(0.0537)\end{array}$ & $\begin{array}{c}0.1295 * * \\
(0.0569)\end{array}$ \\
\hline Hours 26-35 & $\begin{array}{c}0.0858 * * * \\
(0.0215)\end{array}$ & $\begin{array}{c}0.0868 * * * \\
(0.0220)\end{array}$ & $\begin{array}{c}0.0914 * * * \\
(0.0217)\end{array}$ & $\begin{array}{c}0.0866 * * * \\
(0.0215)\end{array}$ \\
\hline Hours 41-45 & $\begin{array}{c}0.0063 \\
(0.0300)\end{array}$ & $\begin{array}{c}0.0077 \\
(0.0376)\end{array}$ & $\begin{array}{c}0.0183 \\
(0.0296)\end{array}$ & $\begin{array}{c}0.0110 \\
(0.0377)\end{array}$ \\
\hline Hours $>45$ & $\begin{array}{c}-0.3054 * * * \\
(0.0300)\end{array}$ & $\begin{array}{c}-0.2930 * * * \\
(0.0367)\end{array}$ & $\begin{array}{c}-0.2899 * * * \\
(0.0312)\end{array}$ & $\begin{array}{c}-0.2908 * * * \\
(0.0369)\end{array}$ \\
\hline Permanent & $\begin{array}{c}0.1793 * * * \\
(0.0254)\end{array}$ & $\begin{array}{c}0.1772 * * * \\
(0.0282)\end{array}$ & $\begin{array}{c}0.1743 * * * \\
(0.0260)\end{array}$ & $\begin{array}{c}0.1766 * * * \\
(0.0272)\end{array}$ \\
\hline Tenure $1-5$ & $\begin{array}{c}0.0194 \\
(0.0260)\end{array}$ & $\begin{array}{l}-0.0093 \\
(0.0340)\end{array}$ & $\begin{array}{c}0.0151 \\
(0.0302)\end{array}$ & $\begin{array}{l}-0.0080 \\
(0.0340)\end{array}$ \\
\hline Tenure 6-10 & $\begin{array}{c}0.0222 \\
(0.0357)\end{array}$ & $\begin{array}{c}0.0225 \\
(0.0431)\end{array}$ & $\begin{array}{c}0.0256 \\
(0.0383)\end{array}$ & $\begin{array}{c}0.0249 \\
(0.0427)\end{array}$ \\
\hline Tenure $>10$ & $\begin{array}{c}0.0117 \\
(0.0358)\end{array}$ & $\begin{array}{c}0.0211 \\
(0.0372)\end{array}$ & $\begin{array}{c}0.0225 \\
(0.0367)\end{array}$ & $\begin{array}{c}0.0223 \\
(0.0369)\end{array}$ \\
\hline First job & $\begin{array}{l}-0.0339 \\
(0.0204)\end{array}$ & $\begin{array}{l}-0.0295 \\
(0.0221)\end{array}$ & $\begin{array}{l}-0.0340 \\
(0.0202)\end{array}$ & $\begin{array}{c}-0.0280 \\
(0.0214)\end{array}$ \\
\hline Over-education & $\begin{array}{c}-0.3370 * * * \\
(0.0316)\end{array}$ & $\begin{array}{c}-0.2925 * * * \\
(0.0371)\end{array}$ & $\begin{array}{c}-0.3252 * * * \\
(0.0347)\end{array}$ & $\begin{array}{c}-0.2862 * * * * \\
(0.0375)\end{array}$ \\
\hline Workday & $\begin{array}{c}0.0062 \\
(0.0254)\end{array}$ & $\begin{array}{c}0.0254 \\
(0.0230)\end{array}$ & $\begin{array}{c}0.0218 \\
(0.0225)\end{array}$ & $\begin{array}{c}0.0259 \\
(0.0220)\end{array}$ \\
\hline Night shift & $\begin{array}{c}-0.1362 * * * \\
(0.0292)\end{array}$ & $\begin{array}{c}-0.1567 * * * \\
(0.0337)\end{array}$ & $\begin{array}{c}-0.1291 * * * \\
(0.0277)\end{array}$ & $\begin{array}{c}-0.1479 * * * * \\
(0.0340)\end{array}$ \\
\hline Firm size $11-50$ & $\begin{array}{c}0.0453 * * \\
(0.0207)\end{array}$ & $\begin{array}{c}0.0299 \\
(0.0270)\end{array}$ & $\begin{array}{l}0.0421^{*} \\
(0.0234)\end{array}$ & $\begin{array}{c}0.0335 \\
(0.0272)\end{array}$ \\
\hline
\end{tabular}




$\begin{array}{lcccc}\text { Firm size 51-250 } & 0.0690 * * & 0.0717 * * & 0.0721 * * & 0.0769 * * \\ & (0.0277) & (0.0312) & (0.0315) & (0.0313) \\ \text { Firm size }>250 & -0.0117 & -0.0006 & -0.0099 & 0.0016 \\ & (0.0315) & (0.0263) & (0.0316) & (0.0263) \\ \text { Industry } & 0.4043 * * * & 0.4092 * * * & 0.4419 * * * & 0.4128 * * * \\ & (0.1050) & (0.1367) & (0.1189) & (0.1360) \\ \text { Construction } & 0.4172 * * * & 0.3652 * * & 0.4310 * * * & 0.3554 * * \\ & (0.1042) & (0.1365) & (0.1100) & (0.1345) \\ \text { Services } & 0.3571 * * * & 0.2922 * * & 0.3679 * * * & 0.2860 * * \\ & (0.0974) & (0.1287) & (0.1093) & (0.1267) \\ \text { GDP } & 0.0000 & 0.0001 & 0.0001 & 0.0001 \\ & (0.0001) & (0.0001) & (0.0001) & (0.0001) \\ \text { Unemployment rate } & -0.0074 & -0.0054 & -0.0050 & -0.0029 \\ & (0.0186) & (0.0187) & (0.0187) & (0.0180) \\ \text { January min temp } & 0.0063 & 0.0081 & 0.0056 & 0.0075 \\ & (0.0116) & (0.0139) & (0.0120) & (0.0140) \\ \text { July max temp } & -0.0145 * & -0.0234 * * & -0.0168 * & -0.0242 * * \\ & (0.0072) & (0.0099) & (0.0094) & (0.0099) \\ \text { Mean annual } & -0.0001 & -0.0001 & -0.0002 & -0.0001 \\ \text { precipitation } & & & & \\ & & & & \\ \text { PM } 10 & (0.0001) & (0.0001) & (0.0001) & (0.0001) \\ \text { VENTILATION } & -0.0004 * * & -0.0006 * * * & -0.0004 * * * & -0.0006 * * * \\ \text { NOISE } & (0.0001) & (0.0002) & (0.0001) & (0.0002) \\ & & 0.0631 * * * & & 0.0577 * * * \\ \text { Year dummies } & & (0.0054) & & (0.0057) \\ \text { Region dummies } & \text { Yes } & & 0.0357 * * * & 0.0247 * * * \\ \text { Occupation dummies } & \text { Yes } & \text { Yes } & (0.0032) & (0.0033) \\ \text { Constant } & 7.0418 * * * & 6.7200 * * * & 6.6107 * * * & 6.4629 * * * \\ & (1.7777) & (1.6602) & (1.8633) & (1.6450)\end{array}$

Observations 32,317

R-squared

Notes: Robust standard errors clustered at the regional level in parentheses. *, **, *** indicate statistical significance at the $10 \%, 5 \%$ and $1 \%$ level, respectively. 
Table 3. IV estimates of the effect of self-perceived noise levels on life satisfaction.

First-stage: the effect of the noise reform in Castile-Leon on self-perceived noise levels

$\begin{array}{lcc}\text { DD } & 4.8073 * * * & 3.6216 * * * \\ & (1.1824) & (1.0848) \\ \text { Observations } & 32317 & 32317 \\ \text { R-squared } & 0.120 & 0.335 \\ \text { Partial R-squared } & 0.0006 & 0.0004 \\ \text { F-test of excl. } & 16.53 & 11.15 \\ \text { p-value } & 0.0009 & 0.0042\end{array}$

Second-stage: the effect of self-perceived noise on life satisfaction

$\begin{array}{lcc}\text { Log income } & 0.3087 * * * & 0.3088 * * * \\ & (0.0244) & (0.0246) \\ \mathrm{PM}_{10} & -0.0003 * * * & -0.0004 * * * \\ & (0.0001) & (0.0001) \\ \text { NOISE } & 0.0291 * * * & 0.0368 * * \\ & (0.0096) & (0.0127) \\ \text { VENTILATION } & & 0.0104 * * \\ & & (0.0042)\end{array}$

$\begin{array}{lll}\text { Observations } \quad 32,317 & 32,317\end{array}$

R-squared $\quad 0.069 \quad 0.070$

Notes: All other controls as per Table 2 are included but not reported. Robust standard errors clustered at the regional level in parentheses. *,**,*** indicate statistical significance at the $10 \%$, $5 \%$ and $1 \%$ level, respectively. 
Table 4. Robustness tests of the effect of the noise reform in Castile-Leon on selfperceived workplace environmental levels.

\begin{tabular}{|c|c|}
\hline Robustness tests & $\begin{array}{l}\text { Coef. } \\
\text { (SE) }\end{array}$ \\
\hline \multicolumn{2}{|l|}{ Common trends } \\
\hline DD & $\begin{array}{c}3.6496 * * \\
(1.4778)\end{array}$ \\
\hline Treatment $\mathrm{X}$ year trend & $\begin{array}{c}0.1838 \\
(0.4029)\end{array}$ \\
\hline \multicolumn{2}{|l|}{ Abadie and Gardeazabal (2003) } \\
\hline DD & $\begin{array}{c}3.6656 * * \\
(1.6200)\end{array}$ \\
\hline \multicolumn{2}{|l|}{ Placebo tests } \\
\hline DD (The effect of the noise reform in Castilla- & 0.0763 \\
\hline & $(0.0998)$ \\
\hline DD (Reform 2007) & $\begin{array}{c}0.4403 \\
(0.7402)\end{array}$ \\
\hline DD (Reform 2008) & $\begin{array}{c}0.0636 \\
(1.0391)\end{array}$ \\
\hline
\end{tabular}

Notes: All other controls as per Table 2 are included but not reported. Robust standard errors clustered at the regional level in parentheses. ${ }^{* *}$ indicates statistical significance at the $5 \%$ level. 
Table 5. Monetary value of outdoor and indoor environmental pollution

\begin{tabular}{lcc}
\hline & $\begin{array}{c}\text { Monetary value } \\
(\mathrm{SE})\end{array}$ & $\begin{array}{c}\text { Monetary value } \\
(\mathrm{SE})\end{array}$ \\
\hline WTP for a $50 \mu \mathrm{g} / \mathrm{m}^{3}$ reduction in & $€ 17.7242^{* * *}$ & $€ 20.2443^{* * *}$ \\
$\mathrm{PM}_{10}$ for one day & $(6.2715)$ & $(5.9052)$ \\
WTP for a one point scale increase & $€ 1,482.959 * * *$ & $€ 1,877.476^{* * *}$ \\
on NOISE conditions & $(483.179)$ & $(636.5777)$ \\
& & $€ 530.2536^{* *}$ \\
WTP for a one point scale increase & & $(208.6736)$ \\
on VENTILATION conditions & & \\
\hline Note: ** and $* * *$ indicate statistical significance at the 5\% and 1\% level, respectively.
\end{tabular}

Note: $* *$ and $* * *$ indicate statistical significance at the $5 \%$ and $1 \%$ level, respectively. 
Table A.1. Effect of outdoor and indoor environmental conditions on life satisfaction (Ordered Probit)

\begin{tabular}{|c|c|c|c|c|}
\hline & (1) & (12) & (23) & (34) \\
\hline \multirow[t]{2}{*}{ Male } & 0.0298 & 0.0324 & 0.0337 & 0.0350 \\
\hline & $(0.0229)$ & $(0.0223)$ & $(0.0235)$ & $(0.0228)$ \\
\hline \multirow[t]{2}{*}{ Age } & $-0.0567 * * *$ & $-0.0553 * * *$ & $-0.0564 * * *$ & $-0.0552 * * *$ \\
\hline & $(0.0043)$ & $(0.0043)$ & $(0.0043)$ & $(0.0043)$ \\
\hline \multirow[t]{2}{*}{$\mathrm{Age}^{2} / 100$} & $0.0584 * * *$ & $0.0562 * * *$ & $0.0575 * * *$ & $0.0558 * * *$ \\
\hline & $(0.0050)$ & $(0.0050)$ & $(0.0050)$ & $(0.0050)$ \\
\hline \multirow[t]{2}{*}{ Spanish } & $0.2160 * * *$ & $0.2208 * * *$ & $0.2185^{* * *}$ & $0.2221 * * *$ \\
\hline & $(0.0237)$ & $(0.0242)$ & $(0.0235)$ & $(0.0240)$ \\
\hline \multirow{2}{*}{$\begin{array}{l}\text { Post- } \\
\text { compulsory }\end{array}$} & 0.0194 & 0.0220 & 0.0181 & 0.0207 \\
\hline & $(0.0169)$ & $(0.0176)$ & $(0.0165)$ & $(0.0171)$ \\
\hline \multirow[t]{2}{*}{ Higher } & $0.0314 *$ & $0.0410 * *$ & $0.0309 * *$ & $0.0395 * *$ \\
\hline & $(0.0166)$ & $(0.0164)$ & $(0.0153)$ & $(0.0154)$ \\
\hline \multirow[t]{2}{*}{ Married } & $0.3644 * * *$ & $0.3671 * * *$ & $0.3658 * * *$ & $0.3678 * * *$ \\
\hline & $(0.0173)$ & $(0.0163)$ & $(0.0166)$ & $(0.0159)$ \\
\hline \multirow[t]{2}{*}{ Family size } & $-0.0288 * * *$ & $-0.0306 * * *$ & $-0.0305 * * *$ & $-0.0317 * * *$ \\
\hline & $(0.0058)$ & $(0.0058)$ & $(0.0059)$ & $(0.0059)$ \\
\hline \multirow[t]{2}{*}{ Care } & $-0.1553 * * *$ & $-0.1530 * * *$ & $-0.1518 * * *$ & $-0.1507 * * *$ \\
\hline & $(0.0116)$ & $(0.0114)$ & $(0.0114)$ & $(0.0115)$ \\
\hline \multirow[t]{2}{*}{ Single-earner } & $-0.0995 * * *$ & $-0.1025 * * *$ & $-0.1030 * * *$ & $-0.1047 * * *$ \\
\hline & $(0.0098)$ & $(0.0098)$ & $(0.0097)$ & $(0.0097)$ \\
\hline \multirow[t]{2}{*}{ Log income } & $0.1651 * * *$ & $0.1603 * * *$ & $0.1638 * * *$ & $0.1600 * * *$ \\
\hline & $(0.0140)$ & $(0.0145)$ & $(0.0140)$ & $(0.0145)$ \\
\hline \multirow[t]{2}{*}{ Public sector } & $0.0331 * *$ & $0.0472 * * *$ & $0.0373 * *$ & $0.0486 * * *$ \\
\hline & $(0.0152)$ & $(0.0153)$ & $(0.0153)$ & $(0.0154)$ \\
\hline \multirow[t]{2}{*}{ Hours $\leq 25$} & $0.1001 * * *$ & $0.0950 * * *$ & $0.1007 * * *$ & $0.0961 * * *$ \\
\hline & $(0.0295)$ & $(0.0296)$ & $(0.0289)$ & $(0.0291)$ \\
\hline \multirow[t]{2}{*}{ Hours 26-35 } & $0.0484 * * *$ & $0.0531 * * *$ & $0.0519 * * *$ & $0.0551 * * *$ \\
\hline & $(0.0128)$ & $(0.0122)$ & $(0.0120)$ & $(0.0117)$ \\
\hline \multirow[t]{2}{*}{ Hours 41-45 } & 0.0101 & 0.0087 & 0.0123 & 0.0105 \\
\hline & $(0.0173)$ & $(0.0182)$ & $(0.0180)$ & $(0.0186)$ \\
\hline \multirow[t]{2}{*}{ Hours $>45$} & $-0.1565^{* * *}$ & $-0.1577 * * *$ & $-0.1541 * * *$ & $-0.1558 * * *$ \\
\hline & $(0.0188)$ & $(0.0185)$ & $(0.0192)$ & $(0.0189)$ \\
\hline \multirow[t]{2}{*}{ Permanent } & $0.1068 * * *$ & $0.1020 * * *$ & $0.1056 * * *$ & $0.1017 * * *$ \\
\hline & $(0.0135)$ & $(0.0145)$ & $(0.0138)$ & $(0.0147)$ \\
\hline \multirow[t]{2}{*}{ Tenure 1-5 } & -0.0023 & 0.0082 & 0.0010 & 0.0093 \\
\hline & $(0.0150)$ & $(0.0147)$ & $(0.0153)$ & $(0.0150)$ \\
\hline \multirow[t]{2}{*}{ Tenure 6-10 } & -0.0033 & 0.0121 & 0.0049 & 0.0162 \\
\hline & $(0.0238)$ & $(0.0232)$ & $(0.0233)$ & $(0.0232)$ \\
\hline \multirow[t]{2}{*}{ Tenure $>10$} & -0.0169 & 0.0072 & -0.0066 & 0.0118 \\
\hline & (0.0198) & $(0.0213)$ & $(0.0206)$ & $(0.0219)$ \\
\hline \multirow[t]{2}{*}{ First job } & $-0.0232 *$ & $-0.0264 * *$ & $-0.0253 * *$ & $-0.0275 * *$ \\
\hline & $(0.0121)$ & $(0.0132)$ & $(0.0114)$ & $(0.0126)$ \\
\hline \multirow[t]{2}{*}{ Over-education } & $-0.1843 * * *$ & $-0.1637 * * *$ & $-0.1730 * * *$ & $-0.1579 * * *$ \\
\hline & $(0.0168)$ & $(0.0159)$ & $(0.0169)$ & $(0.0160)$ \\
\hline \multirow[t]{2}{*}{ Workday } & 0.0033 & 0.0081 & 0.0022 & 0.0067 \\
\hline & $(0.0147)$ & $(0.0138)$ & $(0.0137)$ & $(0.0131)$ \\
\hline Night shift & $-0.0710^{* * *}$ & $-0.0747 * * *$ & $-0.0645 * * *$ & $-0.0695 * * *$ \\
\hline
\end{tabular}




\begin{tabular}{|c|c|c|c|c|}
\hline \multirow{3}{*}{ Firm size $11-50$} & $(0.0154)$ & $(0.0157)$ & $(0.0149)$ & $(0.0154)$ \\
\hline & $0.0247 * *$ & $0.0340 * * *$ & $0.0275 * *$ & $0.0349 * * *$ \\
\hline & $(0.0112)$ & $(0.0107)$ & $(0.0118)$ & $(0.0112)$ \\
\hline \multirow{2}{*}{$\begin{array}{l}\text { Firm size 51- } \\
250\end{array}$} & $0.0355^{* *}$ & $0.0566 * * *$ & $0.0460 * * *$ & $0.0617 * * *$ \\
\hline & $(0.0167)$ & $(0.0168)$ & $(0.0167)$ & $(0.0167)$ \\
\hline \multirow[t]{2}{*}{ Firm size $>250$} & -0.0034 & 0.0179 & 0.0041 & 0.0208 \\
\hline & $(0.0189)$ & $(0.0180)$ & $(0.0193)$ & $(0.0184)$ \\
\hline \multirow[t]{2}{*}{ Industry } & $0.2091 * * *$ & $0.2082 * * *$ & $0.2153 * * *$ & $0.2128 * * *$ \\
\hline & $(0.0579)$ & $(0.0582)$ & $(0.0570)$ & $(0.0575)$ \\
\hline \multirow[t]{2}{*}{ Construction } & $0.2136 * * *$ & $0.1946 * * *$ & $0.2073 * * *$ & $0.1922 * * *$ \\
\hline & $(0.0555)$ & $(0.0550)$ & $(0.0541)$ & $(0.0541)$ \\
\hline \multirow[t]{2}{*}{ Services } & $0.1922 * * *$ & $0.1756^{* * *}$ & $0.1852 * * *$ & $0.1725 * * *$ \\
\hline & $(0.0526)$ & $(0.0533)$ & $(0.0514)$ & $(0.0524)$ \\
\hline \multirow[t]{2}{*}{ GDP } & 0.0000 & 0.0000 & 0.0000 & 0.0000 \\
\hline & $(0.0001)$ & $(0.0001)$ & $(0.0001)$ & $(0.0001)$ \\
\hline \multirow{2}{*}{$\begin{array}{l}\text { Unemployment } \\
\text { rate }\end{array}$} & -0.0020 & -0.0037 & -0.0019 & -0.0034 \\
\hline & $(0.0114)$ & $(0.0114)$ & $(0.0109)$ & $(0.0110)$ \\
\hline \multirow{2}{*}{$\begin{array}{l}\text { January min } \\
\text { temp }\end{array}$} & 0.0035 & 0.0040 & 0.0037 & 0.0041 \\
\hline & $(0.0076)$ & $(0.0075)$ & $(0.0074)$ & $(0.0074)$ \\
\hline \multirow[t]{2}{*}{ July max temp } & $-0.0098 * *$ & $-0.0107 * *$ & $-0.0103 * *$ & $-0.0109 * *$ \\
\hline & $(0.0045)$ & $(0.0049)$ & $(0.0049)$ & $(0.0052)$ \\
\hline \multirow{2}{*}{$\begin{array}{l}\text { Mean annual } \\
\text { precipitation }\end{array}$} & -0.0001 & -0.0001 & -0.0001 & -0.0001 \\
\hline & $(0.0001)$ & $(0.0001)$ & $(0.0001)$ & $(0.0001)$ \\
\hline \multirow[t]{2}{*}{$\mathrm{PM}_{10}$} & $-0.0002 * * *$ & $-0.0002 * * *$ & $-0.0002 * * *$ & $-0.0002 * * *$ \\
\hline & $(0.0001)$ & $(0.0001)$ & $(0.0001)$ & $(0.0001)$ \\
\hline \multirow[t]{2}{*}{ VENTILATION } & & $0.2202 * * *$ & & $0.1938 * * *$ \\
\hline & & $(0.0110)$ & & $(0.0108)$ \\
\hline \multirow[t]{2}{*}{ NOISE } & & & $0.1274 * * *$ & $0.0935 * * *$ \\
\hline & & & $(0.0101)$ & $(0.0096)$ \\
\hline Year dummies & Yes & Yes & Yes & Yes \\
\hline $\begin{array}{l}\text { Region } \\
\text { dummies }\end{array}$ & Yes & Yes & Yes & Yes \\
\hline \multicolumn{5}{|l|}{ dummies } \\
\hline Observations & \multicolumn{4}{|c|}{32,317} \\
\hline
\end{tabular}

Note: $*, * *, * * *$ indicate statistical significance at the $10 \%, 5 \%$ and $1 \%$ level, respectively. 
Table A.2. Effect of outdoor and indoor environmental conditions on life satisfaction (POLS)

\begin{tabular}{|c|c|c|c|c|}
\hline & $(1)$ & $(2)$ & (3) & (4) \\
\hline \multirow[t]{2}{*}{ Male } & 0.0180 & 0.0201 & 0.0213 & 0.0223 \\
\hline & $(0.0149)$ & $(0.0146)$ & $(0.0152)$ & $(0.0148)$ \\
\hline \multirow[t]{2}{*}{ Age } & $-0.0444 * * *$ & $-0.0428 * * *$ & $-0.0439 * * *$ & $-0.0426 * * *$ \\
\hline & $(0.0036)$ & $(0.0037)$ & $(0.0036)$ & $(0.0036)$ \\
\hline \multirow[t]{2}{*}{$\operatorname{Age}^{2} / 100$} & $0.0459 * * *$ & $0.0436 * * *$ & $0.0449 * * *$ & $0.0432 * * *$ \\
\hline & $(0.0043)$ & $(0.0043)$ & $(0.0043)$ & $(0.0043)$ \\
\hline \multirow[t]{2}{*}{ Spanish } & $0.1831 * * *$ & $0.1854 * * *$ & $0.1843^{* * *}$ & $0.1860 * * *$ \\
\hline & $(0.0238)$ & $(0.0238)$ & $(0.0235)$ & $(0.0237)$ \\
\hline \multirow[t]{2}{*}{ Post-compulsory } & 0.0145 & 0.0168 & 0.0134 & 0.0157 \\
\hline & $(0.0143)$ & $(0.0147)$ & $(0.0140)$ & $(0.0144)$ \\
\hline \multirow[t]{2}{*}{ Higher } & $0.0328 *$ & $0.0408 * *$ & $0.0325 * *$ & $0.0396 * *$ \\
\hline & $(0.0156)$ & $(0.0153)$ & $(0.0145)$ & $(0.0145)$ \\
\hline \multirow[t]{2}{*}{ Married } & $0.2813 * * *$ & $0.2808 * * *$ & $0.2811 * * *$ & $0.2807 * * *$ \\
\hline & $(0.0100)$ & $(0.0094)$ & $(0.0096)$ & $(0.0092)$ \\
\hline \multirow[t]{2}{*}{ Family size } & $-0.0190 * * *$ & $-0.0204 * * *$ & $-0.0204 * * *$ & $-0.0212 * * *$ \\
\hline & $(0.0052)$ & $(0.0051)$ & $(0.0052)$ & $(0.0051)$ \\
\hline \multirow[t]{2}{*}{ Care } & $-0.1203 * * *$ & $-0.1171 * * *$ & $-0.1167 * * *$ & $-0.1150 * * *$ \\
\hline & $(0.0118)$ & $(0.0112)$ & $(0.0116)$ & $(0.0113)$ \\
\hline \multirow[t]{2}{*}{ Single-earner } & $-0.0798 * * *$ & $-0.0817 * * *$ & $-0.0824 * * *$ & $-0.0834 * * *$ \\
\hline & $(0.0087)$ & $(0.0088)$ & $(0.0086)$ & $(0.0087)$ \\
\hline \multirow[t]{2}{*}{ Log income } & $0.1464 * * *$ & $0.1411 * * *$ & $0.1445^{* * *}$ & $0.1403 * * *$ \\
\hline & $(0.0124)$ & $(0.0126)$ & $(0.0122)$ & $(0.0125)$ \\
\hline \multirow[t]{2}{*}{ Public sector } & $0.0223^{*}$ & $0.0341 * *$ & $0.0256^{*}$ & $0.0351 * *$ \\
\hline & $(0.0126)$ & $(0.0124)$ & $(0.0127)$ & $(0.0125)$ \\
\hline \multirow[t]{2}{*}{ Hours $\leq 25$} & $0.0813 * * *$ & $0.0761 * * *$ & $0.0812 * * *$ & $0.0766 * * *$ \\
\hline & $(0.0234)$ & $(0.0233)$ & $(0.0226)$ & $(0.0227)$ \\
\hline \multirow[t]{2}{*}{ Hours 26-35 } & $0.0352 * * *$ & $0.0388 * * *$ & $0.0380 * * *$ & $0.0405 * * *$ \\
\hline & $(0.0114)$ & $(0.0113)$ & $(0.0107)$ & $(0.0109)$ \\
\hline \multirow[t]{2}{*}{ Hours 41-45 } & 0.0054 & 0.0040 & 0.0073 & 0.0056 \\
\hline & $(0.0153)$ & $(0.0158)$ & $(0.0159)$ & $(0.0162)$ \\
\hline \multirow[t]{2}{*}{ Hours $>45$} & $-0.1293 * * *$ & $-0.1291 * * *$ & $-0.1267 * * *$ & $-0.1273 * * *$ \\
\hline & $(0.0162)$ & $(0.0156)$ & $(0.0164)$ & $(0.0158)$ \\
\hline \multirow[t]{2}{*}{ Permanent } & $0.0917 * * *$ & $0.0870 * * *$ & $0.0903 * * *$ & $0.0865 * * *$ \\
\hline & $(0.0114)$ & $(0.0120)$ & $(0.0116)$ & $(0.0122)$ \\
\hline \multirow[t]{2}{*}{ Tenure 1-5 } & 0.0047 & 0.0138 & 0.0076 & 0.0148 \\
\hline & $(0.0124)$ & $(0.0116)$ & $(0.0124)$ & $(0.0118)$ \\
\hline \multirow[t]{2}{*}{ Tenure 6-10 } & -0.0037 & 0.0097 & 0.0034 & 0.0132 \\
\hline & $(0.0234)$ & $(0.0219)$ & $(0.0226)$ & $(0.0217)$ \\
\hline \multirow[t]{2}{*}{ Tenure $>10$} & -0.0164 & 0.0044 & -0.0074 & 0.0085 \\
\hline & $(0.0142)$ & $(0.0149)$ & $(0.0144)$ & $(0.0152)$ \\
\hline \multirow[t]{2}{*}{ First job } & -0.0075 & -0.0102 & -0.0094 & -0.0112 \\
\hline & $(0.0118)$ & $(0.0125)$ & $(0.0109)$ & $(0.0118)$ \\
\hline \multirow[t]{2}{*}{ Over-education } & $-0.1541 * * *$ & $-0.1351 * * *$ & $-0.1438 * * *$ & $-0.1299 * * *$ \\
\hline & $(0.0152)$ & $(0.0140)$ & $(0.0149)$ & $(0.0140)$ \\
\hline Workday & 0.0086 & 0.0125 & 0.0078 & 0.0114 \\
\hline & $(0.0124)$ & $(0.0118)$ & $(0.0116)$ & $(0.0113)$ \\
\hline Night shift & $-0.0660 * * *$ & $-0.0685 * * *$ & $-0.0603 * * *$ & $-0.0641 * * *$ \\
\hline & $(0.0158)$ & $(0.0156)$ & $(0.0148)$ & $(0.0149)$ \\
\hline
\end{tabular}




\begin{tabular}{|c|c|c|c|c|}
\hline Firm size $11-50$ & $\begin{array}{l}0.0207 * \\
(0.0116)\end{array}$ & $\begin{array}{c}0.0282 * * \\
(0.0112)\end{array}$ & $\begin{array}{l}0.0228 * \\
(0.0120)\end{array}$ & $\begin{array}{c}0.0289 * * \\
(0.0116)\end{array}$ \\
\hline \multirow[t]{2}{*}{ Firm size $51-250$} & $0.0299 *$ & $0.0473 * * *$ & $0.0385 * *$ & $0.0514 * * *$ \\
\hline & $(0.0149)$ & $(0.0148)$ & $(0.0147)$ & $(0.0147)$ \\
\hline \multirow[t]{2}{*}{ Firm size $>250$} & 0.0092 & $0.0271 *$ & 0.0155 & $0.0295 * *$ \\
\hline & $(0.0136)$ & $(0.0133)$ & $(0.0137)$ & $(0.0133)$ \\
\hline \multirow[t]{2}{*}{ Industry } & $0.1856 * * *$ & $0.1834 * * *$ & $0.1902 * * *$ & $0.1870 * * *$ \\
\hline & $(0.0549)$ & $(0.0553)$ & $(0.0540)$ & $(0.0546)$ \\
\hline \multirow[t]{2}{*}{ Construction } & $0.1800 * * *$ & $0.1624 * * *$ & $0.1741 * * *$ & $0.1602 * * *$ \\
\hline & $(0.0533)$ & $(0.0531)$ & $(0.0519)$ & $(0.0522)$ \\
\hline \multirow[t]{2}{*}{ Services } & $0.1692 * * *$ & $0.1538 * * *$ & $0.1626 * * *$ & $0.1509 * * *$ \\
\hline & $(0.0520)$ & $(0.0525)$ & $(0.0508)$ & $(0.0516)$ \\
\hline \multirow[t]{2}{*}{ GDP } & 0.0000 & 0.0000 & 0.0000 & 0.0000 \\
\hline & $(0.0000)$ & $(0.0001)$ & $(0.0000)$ & $(0.0000)$ \\
\hline \multirow{2}{*}{$\begin{array}{l}\text { Unemployment } \\
\text { rate }\end{array}$} & -0.0036 & -0.0050 & -0.0035 & -0.0047 \\
\hline & $(0.0093)$ & $(0.0092)$ & $(0.0088)$ & $(0.0089)$ \\
\hline \multirow[t]{2}{*}{ January min temp } & 0.0003 & 0.0007 & 0.0005 & 0.0008 \\
\hline & $(0.0061)$ & $(0.0060)$ & $(0.0058)$ & $(0.0058)$ \\
\hline \multirow[t]{2}{*}{ July max temp } & $-0.0075^{* *}$ & $-0.0082 * *$ & $-0.0078 * *$ & $-0.0083^{*} *$ \\
\hline & $(0.0033)$ & $(0.0033)$ & $(0.0035)$ & $(0.0035)$ \\
\hline \multirow{2}{*}{$\begin{array}{l}\text { Mean annual } \\
\text { precipitation }\end{array}$} & -0.0001 & -0.0001 & -0.0001 & -0.0001 \\
\hline & $(0.0001)$ & $(0.0001)$ & $(0.0001)$ & $(0.0001)$ \\
\hline \multirow[t]{2}{*}{$\mathrm{PM}_{10}$} & $-0.0002 * *$ & $-0.0002 * * *$ & $-0.0002 * *$ & $-0.0002 * * *$ \\
\hline & $(0.0001)$ & $(0.0001)$ & $(0.0001)$ & $(0.0001)$ \\
\hline \multirow[t]{2}{*}{ VENTILATION } & & $0.1869 * * *$ & & $0.1645^{* * *}$ \\
\hline & & $(0.0080)$ & & $(0.0069)$ \\
\hline \multirow[t]{2}{*}{ NOISE } & & & $0.1073 * * *$ & $0.0779 * * *$ \\
\hline & & & $(0.0100)$ & $(0.0091)$ \\
\hline Year dummies & Yes & Yes & Yes & Yes \\
\hline Region dummies & Yes & Yes & Yes & Yes \\
\hline $\begin{array}{l}\text { Occupation } \\
\text { dummies }\end{array}$ & Yes & Yes & Yes & Yes \\
\hline Constant & $\begin{array}{l}-0.9246 \\
(0.9413)\end{array}$ & $\begin{array}{l}-0.7242 \\
(0.9773)\end{array}$ & $\begin{array}{l}-0.9012 \\
(0.9032)\end{array}$ & $\begin{array}{l}-0.7313 \\
(0.9472)\end{array}$ \\
\hline
\end{tabular}

Observations 32,317

R-squared

0.058

0.074

0.067

0.078

Note: $*, * *, * * *$ indicate statistical significance at the $10 \%, 5 \%$ and $1 \%$ level, respectively. 
Table A.3. Pseudo-panel estimates of the effect of outdoor and indoor environmental conditions on life satisfaction (OLS and cohort FE)

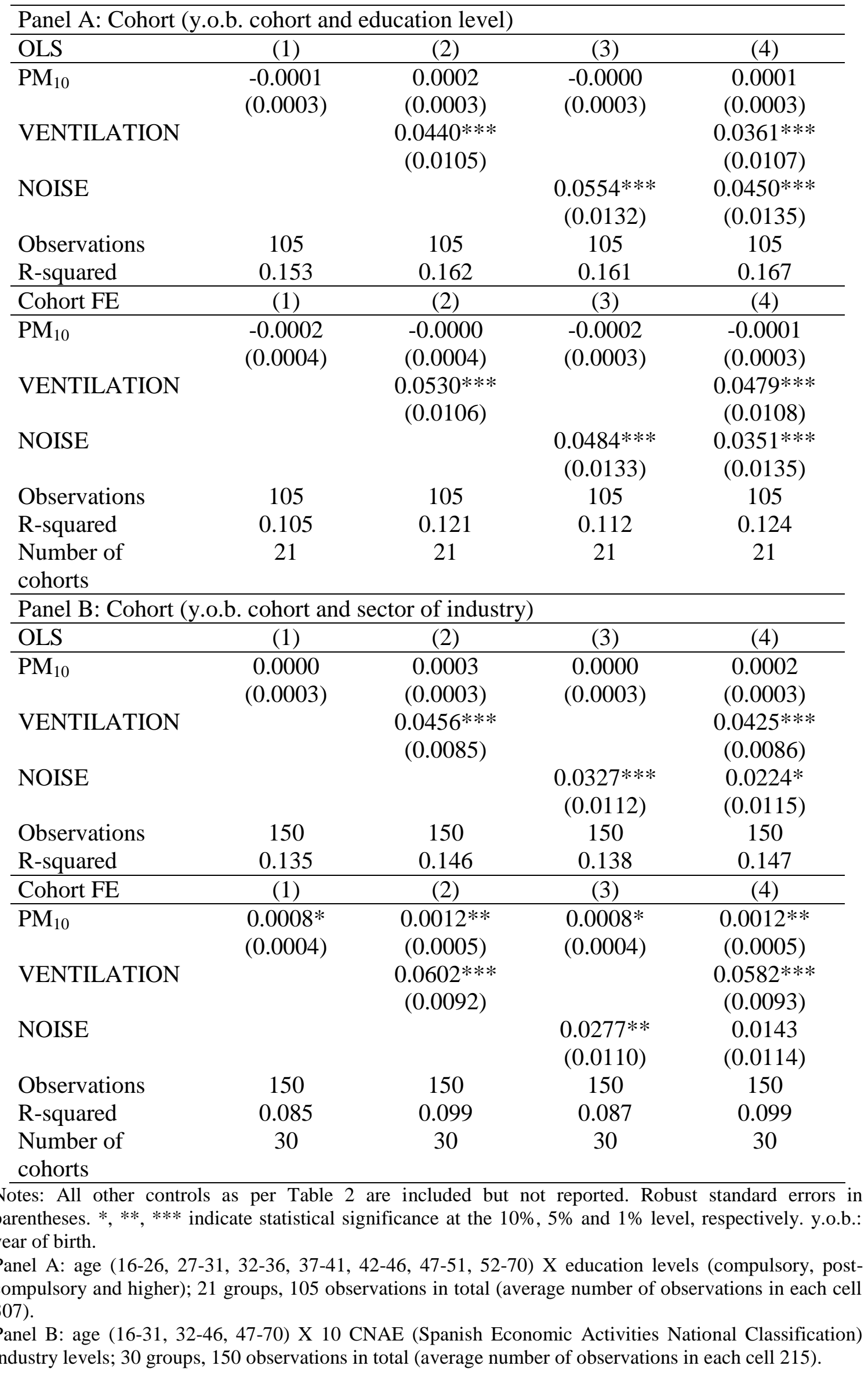

